\title{
The Induced Pluripotent Stem Cells in Articular Cartilage Regeneration and Disease Modelling: Are We Ready for Their Clinical Use?
}

\author{
Michał S. Lach ${ }^{1,2,3, *,+} \mathbb{C}$, Monika A. Rosochowicz ${ }^{1,2,+}{ }^{-}$, Magdalena Richter ${ }^{2} \mathbb{C}^{\text {, Inga Jagiełło }}{ }^{4}$, \\ Wiktoria M. Suchorska ${ }^{1,3}$ (i) and Tomasz Trzeciak ${ }^{2}$ \\ 1 Radiobiology Laboratory, Greater Poland Cancer Centre, 61-866 Poznan, Poland; \\ monika.rosochowicz@interia.eu \\ 2 Department of Orthopedics and Traumatology, Poznan University of Medical Sciences, \\ 61-545 Poznan, Poland; mrichter@ump.edu.pl (M.R.); tomasz.trzeciak@ump.edu.pl (T.T.) \\ 3 Department of Electroradiology, Poznan University of Medical Sciences, 61-866 Poznan, Poland; \\ wiktoria.suchorska@wco.pl \\ 4 Greater Poland Cancer Centre, Department of Tumour Pathology, 61-866 Poznan, Poland; \\ inga.jagiello@wco.pl \\ * Correspondence: michal.lach@wco.pl \\ + These authors contributed equally to this work.
}

check for updates

Citation: Lach, M.S.; Rosochowicz, M.A.; Richter, M.; Jagiełło, I.; Suchorska, W.M.; Trzeciak, T. The Induced Pluripotent Stem Cells in Articular Cartilage Regeneration and Disease Modelling: Are We Ready for Their Clinical Use? Cells 2022, 11, 529. https://doi.org/10.3390/ cells11030529

Academic Editor: Claudia Spits

Received: 19 December 2021

Accepted: 1 February 2022

Published: 3 February 2022

Publisher's Note: MDPI stays neutral with regard to jurisdictional claims in published maps and institutional affiliations.

Copyright: (C) 2022 by the authors. Licensee MDPI, Basel, Switzerland. This article is an open access article distributed under the terms and conditions of the Creative Commons Attribution (CC BY) license (https:// creativecommons.org/licenses/by/ $4.0 /)$.

\begin{abstract}
The development of induced pluripotent stem cells has brought unlimited possibilities to the field of regenerative medicine. This could be ideal for treating osteoarthritis and other skeletal diseases, because the current procedures tend to be short-term solutions. The usage of induced pluripotent stem cells in the cell-based regeneration of cartilage damages could replace or improve on the current techniques. The patient's specific non-invasive collection of tissue for reprogramming purposes could also create a platform for drug screening and disease modelling for an overview of distinct skeletal abnormalities. In this review, we seek to summarise the latest achievements in the chondrogenic differentiation of pluripotent stem cells for regenerative purposes and disease modelling.
\end{abstract}

Keywords: iPSC; osteoarthritis; stem cells; disease modelling; chondrodysplasias; regenerative medicine

\section{Introduction}

Over a decade has passed since the Yamanaka group developed the reprogramming process, which revolutionised the usage of pluripotent stem cells in the field of regenerative medicine and created hitherto unimaginable possibilities. However, modifying the cell culture conditions to manipulate these cells toward the desired one remains challenging. Bioengineers and clinicians are looking for efficient cartilage regeneration methods to treat injuries and reduce the deterioration in the quality of life caused by osteoarthritis (OA) [1-6]. Soon, the distinct disabilities regarding the development of OA will gain the status of a civilisation disease due to their increasing percentage of the elderly population, especially in well-developed countries $[5,7,8]$. As osteoarthritis progresses, the biomechanical properties of the joint are altered, causing pain and stiffness and limiting the range of motion $[8,9]$. The lack of symptoms at the early stages of OA rules out non-invasive treatment to prevent further progress of the disease $[5,10,11]$. The development of OA is related to the remodelling of the articular cartilage extracellular matrix (ECM) caused by the matrix metalloproteinases (MMP) and disintegrins and metalloproteinases with thrombospondin motif (ADAMTS) [12].

The articular cartilage matrix is enriched with collagens (type IX, II, and XI); laminin; and elastin. Additionally incumbent are proteoglycans containing hyaluronic acid, chondroitin sulphate, and keratan sulphate [13-15]. The proportion of water in cartilage tissue 
(70-80\%) also increases the resistance of cartilage to mechanical stress, forces ranging from 1 to $4 \mathrm{MPa}$, and facilitates joint movement $[16,17]$. The articular cartilage may distinguish three functional regions: the superficial, middle, and deep zones. The superficial zone is enriched with lubricin, hyaluronic acid, and flattened chondrocytes. These are responsible for sustaining homogenous joint surfaces and reducing the friction forces. The collagen fibres are also parallel to each other. The middle zone is composed of dense ECM with increased amounts of proteoglycans and is responsible for high osmotic pressure, the distribution of mechanical forces and resilience. There are randomly located spherical chondrocytes, and chaotically distributed fibres may be found. The deep zone is characterised by enlarged, mature chondrocytes, clearly expressing collagen type $X$, in which the fibres are oriented perpendicularly $[18,19]$. Due to the avascular nature of cartilage, a dense ECM enables the exchange of nutrition and waste products by diffusion from the synovial fluid and subchondral bone [14,20-22].

Therefore, new approaches are required to eliminate or prolong the useful life of the most invasive procedures, extending the patients' quality of life and activity. This is the socioeconomic burden of ageing societies. The new technologies and discoveries in the field of regenerative medicine, especially regarding the usage of induced pluripotent stem cells, could yield a solution to the possible future increase in cases of disabilities caused by OA. These alternatives could improve or replace the existing surgical procedures, which have drawbacks (detailed in the next section).

In this review, we focus on the recent discoveries regarding the development of suitable differentiation protocols of human-induced pluripotent stem cells into chondrogenic populations and their possible role in clinic and disease modelling.

\section{The Surgical Methods in OA Treatment}

The standard therapeutic procedures of articular cartilage repair involve the regeneration of the cartilage with autologous chondrocyte implantation (ACI), matrix-induced autologous chondrocyte implantation (MACI), microfracture, mosaicplasty, and the most extensive option of total joint arthroplasty. These procedures have both advantages and disadvantages, summarised in Table 1.

Table 1. A summary of the most used techniques for the repair of damaged cartilage.

\begin{tabular}{|c|c|c|c|c|}
\hline Technique Repair & & Advantages & Disadvantages & Ref \\
\hline MACI & $\begin{array}{l}+ \\
+ \\
+ \\
+ \\
+\end{array}$ & $\begin{array}{l}\text { cells seeded on scaffolds } \\
\text { lack of leakage from periosteal patch } \\
\text { speedy recovery } \\
\text { less invasive } \\
\text { improved mobility }\end{array}$ & $\begin{array}{ll}- & \text { fibrocartilage formation } \\
- & \text { expensive method of treatment } \\
- & \text { requires two surgeries } \\
- & \text { limited to small lesions }\end{array}$ & {$[23,24]$} \\
\hline $\mathrm{ACI}$ & $\begin{array}{l}+ \\
+ \\
+ \\
+ \\
+\end{array}$ & $\begin{array}{l}\text { speedy recovery } \\
\text { less invasive } \\
\text { improved mobility } \\
\text { reduced pain } \\
\text { increased joint motion }\end{array}$ & $\begin{array}{ll}\text { - } & \text { requires two surgeries } \\
- & \text { limited to active young people } \\
- & \text { chondrocyte dedifferentiation } \\
- & \text { leakage of cells from periosteal patch } \\
- & \text { damage to healthy tissue } \\
- & \text { dedifferentiation of chondrocytes } \\
- & \text { fibrocartilage formation } \\
- & \text { limited to small lesions }\end{array}$ & {$[22,25,26]$} \\
\hline Microfracture & $\begin{array}{l}+ \\
+ \\
+\end{array}$ & $\begin{array}{l}\text { one-step surgery } \\
\text { low cost } \\
\text { simple, non-invasive procedure. }\end{array}$ & $\begin{array}{l}\text { - } \quad \text { fibrocartilage is formed } \\
\text { - } \quad \text { age limit } \\
\text { the necessity of subsequent surgeries } \\
\text { in the long term }\end{array}$ & {$[4,27-29]$} \\
\hline
\end{tabular}


Table 1. Cont.

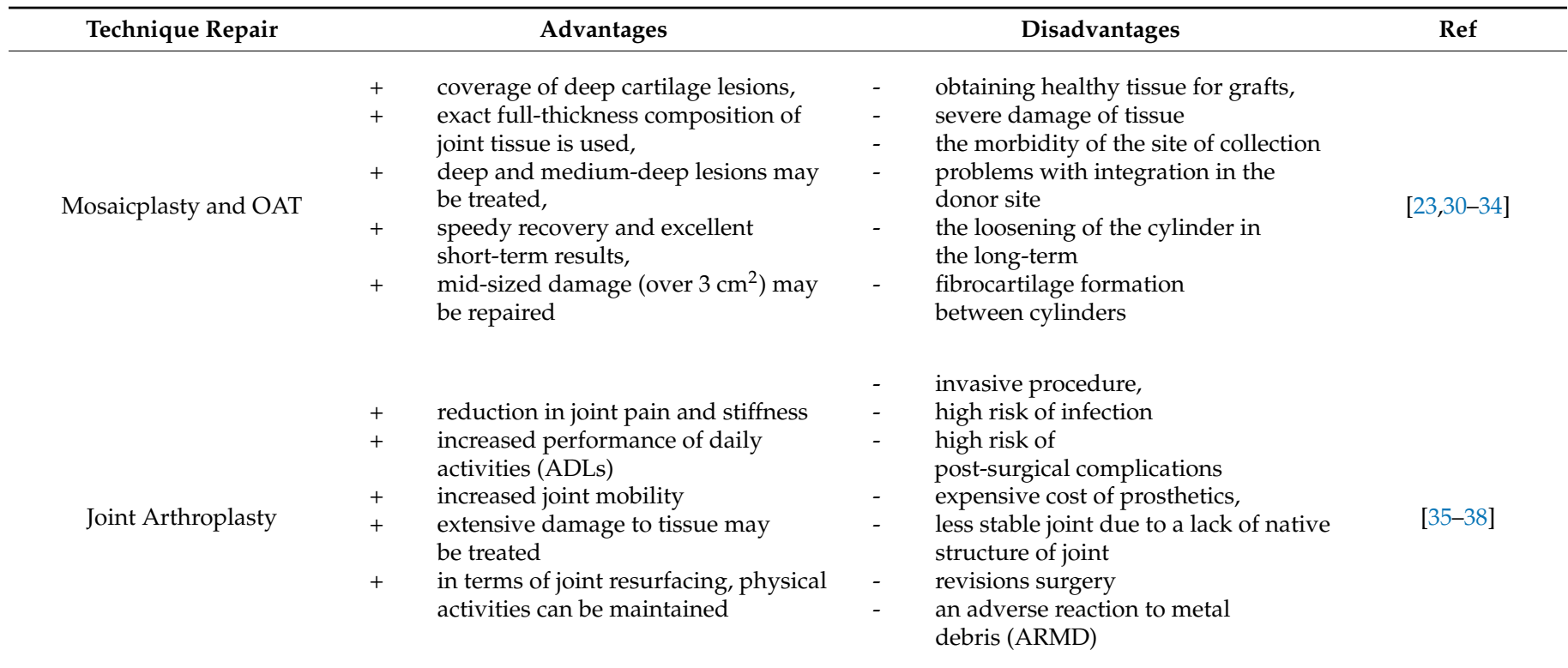

ACI: autologous chondrocyte implantation; ADL: daily activities; ARMD: an adverse reaction to metal debris MACI: matrix-induced autologous chondrocyte implantation; OAT: osteochondral autograft transplant.

Briefly, in the ACI, chondrocytes removed from the patient are propagated in vitro. They undergo dedifferentiation, reducing the expression of type II collagen and proteoglycans. The number of cells required for the repair procedure is obtained but represents a diminished functionality. There is a problem concerning the dedifferentiation of chondrocytes after implantation; hence, fibrocartilage formation is observed more than the expected hyaline cartilage [39-42]. Another limitation of this technique is the donor's age, since the number of chondrocytes capable of proliferating and producing functional cartilage decreases with age [1].

MACI is a modified ACI procedure. The main difference between the techniques is the application of collagen matrices seeded with autologous chondrocytes. This resolves the problem of periosteal patch leakage, one of the side effects of ACI [13]. ACI and MACI result in patients' relatively quick recovery after surgery [43]. Still, these current techniques have some severe disadvantages. The main problem is the scarcity of cells postimplantation. Chondrocytes constitute only $2 \%$ of the whole cartilage, which complicates the autotransplantation of cells and requires the damage of healthy tissue to obtain sufficient cells. These procedures are also performed on active young patients. Ultimately, it is not a long-term solution due to the formation of fibrocartilage in place of hyaline cartilage, which leads to further damage $[26,44,45]$. On the other hand, microfractures use the potential of bone marrow mesenchymal stem cells (MSCs) to separate into chondrocyte-like cells. However, the regenerated tissue shows fibrocartilage properties, which changes the biomechanical functions of the joint and yields unsatisfactory results in the long term $[42,46]$. The benefit of microfractures comes from their simplicity, low costs, and requiring a singlestep surgical procedure [47].

These procedures may also treat substantial full-thickness defects using mosaicplasty or osteochondral autograft transplant (OAT) [48]. This procedure is quite simple and could be performed arthroscopically but is longer and more complex than a microfracture [49]. The osteochondral plug is collected from the low-bearing site of the joint and then placed in the damaged area. The graft is generally well-built-up in the surrounding bone but less efficient in the site of hyaline cartilage [50]. The cyclic pressure on the graft may mean that some loosening may occur in the long term, and more significant defects may develop, as with other techniques $[23,48]$. This procedure may have better outcomes than microfractures but fewer than ACI [47]. 
Even these techniques fail to rule out patients finally undergoing the most invasive procedure, i.e., joint arthroplasty $[4,35]$. This procedure reduces the pain and stiffness but also limits activity post-surgery. The costs of materials used for manufacturing implants are also high. After a couple of years, revision surgery is necessary to replace the worn implants, and this causes a higher risk of the development of septic or aseptic loosening of part of the implants [51].

\section{3. iPS Cells Definition}

Induced pluripotent stem cells (iPSC) are a specific type of cells that may be generated from somatic cells through reprogramming, enabling them to possess embryonic-like properties. Shinya Yamanaka's group initially derived them in 2006 by reprogramming mouse fibroblasts and human fibroblasts the following year $[52,53]$. They showed that somatic cells may be converted into pluripotent stem cells by using transcription factors encoded by four specific genes: $c-M y c$, octamer-binding transcription factor 4 (OCT4), SRY-box transcription factor-2 (SOX2), and Krüppel-like factor 4 (Klf4) [52]. The iPS cells are similar to embryonic stem cells (ESC), including morphological similarities: flat colonies with precise edges formed from cells with a high nucleus-to-cytoplasm volume ratio and marked as nucleolus. Similar to ES cells, they have high alkaline phosphatase activity. iPS cells have a gene expression profile characteristic of stem cells. Stage-specific embryonic antigen-3 (SSEA3), stage-specific embryonic antigen-4 (SSEA4), and glycoprotein T-cell receptor $\alpha$ locus (TRA 1-60) and TRA 1-81 are presented on the surface. They may also differentiate into cells from three germ layers and be maintained in a nondifferentiated state for an extended period of time to cultivate cells, known as the self-renewal process [54]. The methylation profile between ES and iPS cells is also similar but differs from somatic cells. Promoters of transcriptionally active genes are characterised by the low methylation level of $\mathrm{CpG}$ islands and the presence of the active chromatin marker H3K4me3. Gene promoters responsible for maintaining pluripotency, however, undergo hypomethylation [55]. The determining feature of pluripotency is the reactivation of an inactive $X$ chromosome in female cells and chromatin modifications similar to ESC [56].

Using iPSC cells tends to create less of an ethical dilemma than using ESC cells derived from a human embryo inner cell mass. However, the main limitation of the use of iPS cells is linked to the methods employed to obtain them. Most methods for receiving pluripotent stem cells are related to using viral vectors, such as retroviruses and lentiviruses [57]. These vectors integrate randomly into the host cell's genome, leading to genetic instability or interfering with the appropriate functioning of the integrated genes, and may increase the risk of tumour formation [58]. Recent discoveries, however, have also led to alternative technologies for obtaining iPS cells, such as an adenovirus, plasmid transfusion, or nonintegrating episomal vectors, all of which carry a lower risk of tumour formation [58-60]. It has also been established that chemical stimulation can reduce the oncogenic factors supplied to the cells for reprogramming into iPS cells [61]. Different factors may replace the four primary factors present in the Yamanaka cocktail, but the essential factor OCT4 may not be omitted [62].

It is also worth mentioning the low efficiency of reprogramming. Researchers stress that Yamanaka's initial research into reprogramming cells into iPS cells had a low success rate regarding their acquisition. Studies have also found that the cell reprogramming efficiency increases in cells where the TP53 gene is silenced [63]. Therefore, this could provide genetic stability in cells, and some precautions and strict testing strategies are necessary to reduce the risk of cancer development and confirm their safety [64]. It has been suggested that effective cell reprogramming may potentially reduce the Mbd3/NuRD complex (methyl-CpG-binding domain protein 3/Nucleosome Remodeling and Deacetylation). It has been stressed that nuclear reprogramming is inefficient, and the molecular mechanisms for returning epigenetic states during iPSC production are not entirely understood [65]. Researchers have found that lowering the Mbd3 expression of the NuRD subunit improves the reprogramming efficiency and facilitates the creation of pluripotent stem cells, even in the 
absence of $c-M y c$ and Sox2 [66]. Recent studies have also suggested that Krüppel-associated box domain zinc fingers (KRAB-ZNFs) are responsible for maintaining the pluripotency state by the methylation of genes responsible for pro-differentiation [65].

The above problems lead to another issue commonly related to the grafting of derived tissues and the immunological reactions of recipients [67]. In the case of the autologous transplantation of iPSC-derived tissues, there remains a risk of their rejection [68,69]. It has been suggested that the source of the cells (exhibiting high immunogenicity), late passages of iPSC cultures or by way of reprogramming somatic cells (primarily based on the retroviral vectors), enhances the response to a formed graft [70-72]. The reprogramming of cells with low immunogenic potentials, such as mesenchymal cells and cord blood mesenchymal stem cells, could solve these obstacles $[69,73]$. The recent data also indicated that modifying the expression of MHC-1 class molecules could significantly reduce the rejection of iPSCbased grafts [74]. Another idea is to create the haplotyping of iPSC clones, which results in obtaining universal cell biobanks compatible with the vast majority of potential donors, reducing the cost and time of iPSC derivation for regenerative purposes [75-77].

\section{Comparison of iPSC and MSC}

Mesenchymal stromal cells (MSCs) are multipotent cells that can differentiate into osteoblasts, chondrocytes, myocytes, or adipocytes [78,79]. Across the literature, there is another term used for this population, mesenchymal stem cells. The International Society for Cell and Gene Therapy (ISCT ${ }^{\circledR}$ ) has recently suggested that this term is inappropriate unless the data support their "stem-like" functionality and properties [79]. They are found in the bone marrow (in low amounts: $0.001 \%$ ), fat tissue (a rich source), umbilical blood and cord, and dental pulp [80-82]. The source of these cells should also be indicated and emphasised, because they exhibit different immunomodulatory and paracrine properties [82]. A recent study has shown that bone marrow (BM-MSC), umbilical cord (UC-MSC), and adipose tissue (AT-MSC), all belonging to MSC, had distinct roles in graft-vs-host disease. The AT-MSC- and UC-MSC-derived cells also had higher procoagulant properties, which raises safety concerns [83]. Their application in neuroregenerative purposes, for example, indicated significant differences between BM-MSC, AT-MSC, and UC-MSC secretomes, phenotypes, and growth kinetics, resulting in improved neurite growth in the presence of a conditioned medium from UC- and AT-MSC compared to BM-MSC. However, their protective properties were maintained at a similar level [84]. Some studies have also tested the utility of MSC derived from different sources in cartilage regeneration [81,85,86]. Among them, the best choice for joint regeneration purposes would be the MSC derived from bone marrow $[81,85,86]$. Despite this, their unique features make them an attractive source of cells for a wide range of medical applications. The limitations of these cells are the invasive way they are procured and the limited ability to provide MSC in significant quantities while maintaining a high quality. It should also be emphasised that their proliferative and differentiation potentials decrease with age and in patients with bone or metabolic diseases.

MSCs are large cells with a round cell nucleus, a marked nucleolus, surrounded by finely dispersed chromatin particles. This lends the nucleus a distinct appearance. The cells have an elongated spindle-like shape. One of the essential criteria for MSCs is that they must exhibit adhesion to plastic surfaces (e.g., the plate on which they grow). On the other hand, iPS cells have a large cell nucleus and a small volume of the cytoplasm. They form sharp-edged, flat, and tightly packed colonies [87,88]. MSC and iPS cells differ significantly in terms of expressed surface markers. MSCs express CD105, CD73, and CD90 but not CD45, CD34, CD14, CD11b, CD79 $\alpha$, CD19, or HLA-DR. In contrast, iPS cells may be characterised by the presence of SSEA-3, SSEA-4, TRA-1-60, TRA-1-81, and TRA-2-49/6E and may also display CD30, CD9, CD50, CD200, and CD90 [89].

Both mesenchymal and induced pluripotent stem cells have promising prospects in disease modelling, tissue engineering, and personalised therapy. Recent reports suggest using MSC in treating diseases such as spinal cord injury, heart disease, Alzheimer's disease, Parkinson's disease, type 1 diabetes, burns, strokes, and arthritis [90]. By contrast, 
iPSCs are among the most promising tools for developing regenerative medicine and are most often reprogrammed from fibroblast cultures, cord blood cells, and peripheral blood mononuclear cells [91]. A significant difference between these cells is that MSC cells can only differentiate into mesenchymal germ layer cells, while iPSCs differentiate into cells from all three layers. This property of iPSC cells creates a high risk of teratoma formation due to potential residual cells in newly formed tissue/organs [92]. Creating optimal, safe, and highly efficient differentiation protocols into desired cells is required. The recent data suggest that using iPSC depletion agents from a cell culture after differentiation could resolve this issue. The usage of inhibitors of stearoyl-CoA desaturase (SCD1) or antibodies that recognise lacto-N-fucopentose I (LNFP I) was found to be helpful in that matter due to their higher specificity toward undifferentiated cells [93,94].

Researchers stress that an increasingly promising way to use stem cells is to combine them with scaffolds. This may provide a greater reparative capacity and survival of the cells. Progress in this field is promising for both regenerative medicine and tissue engineering [90]. Due to foetal-like origins, the derivation of progenitors from iPSC could also rejuvenate them, enabling improved adaptation to the pathologically changed diseased area. It was shown in an example of myocardial repair, where iPSC-derived cardiomyocytes significantly improved the ejection fraction with the observable attenuated remodelling of the myocardium into fibrotic tissue [95].

\section{5. iChondrocytes Cell Generation-Protocols}

The search for effective treatment methods for osteoarthritis has given rise to considerable clinical interest in differentiating iPSC into articular cartilage chondrocytes. As mentioned above, the current techniques are insufficient in the long term and are mainly limited to younger patients with small lesions. Damaged human articular cartilage does not heal itself due to a high content of extracellular matrix and a lack of lymphatic, vascular vessels and neural tissue [96]. A protocol that enables a heightened efficiency in obtaining human chondrocytes that would also be safe for the patient needs to be developed. More importantly, the protocol should provide sufficient cells without changing their phenotype, which would provide high-quality hyaline cartilage after implantation. Most of the basic protocols depend on the induction of mesoderm or mesenchymal cells due to their origin. Many attempts have been made to develop such a protocol using various growth factors, such as fibroblast growth factor (FGF), transforming growth factor-beta (TGF- $\beta$ ), platelet-derived growth factor (PDGF), and modulating different signal pathways with chemical agents $[97,98]$. The first well-defined protocol in serum-free and chemically defined conditions deserves a special mention. It was developed by the Oldershaw team and was an essential element in future approaches [99]. Briefly, hESC were differentiated step-by-step by the induction of primitive streak/mesendoderm, further mesoderm, and finally, into chondrocyte progenitors for a short period, i.e., 14 days. This protocol required a combination of at least seven growth factors (WNT3A, activin-A, FGF-2, BMP4, Follistatin, GDF-5, and NT-4) and two matrix substrates (fibronectin and gelatin) [99]. These conditions were recently used and modified by different teams of researchers, as discussed below. Another aspect concerns obtaining chondrocytes without exhibiting hypertrophy or terminal maturation over time, leading to ossification and degradation of the repaired cartilage tissue and, consequently, an advance of the disease [100,101]. The following part of this review will focus on differentiation protocols of iPS cells into chondrogenic populations using directed methods or through an embryoid bodies (EBs) step and additional stimuli to improve the formation of cells of a specific germ layer, methods using a cell-scaffold combination, and methods using physical/chemical agents during differentiation (Figure 1 and Table 2). 
Damaged Cartilage

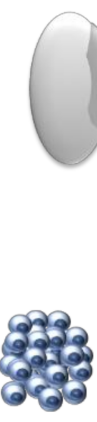

EBs

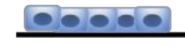

Monolayer
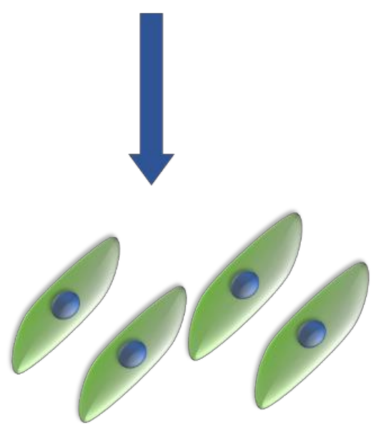

iMSC

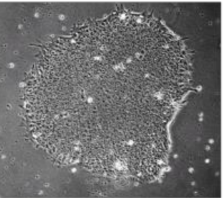

iPSC
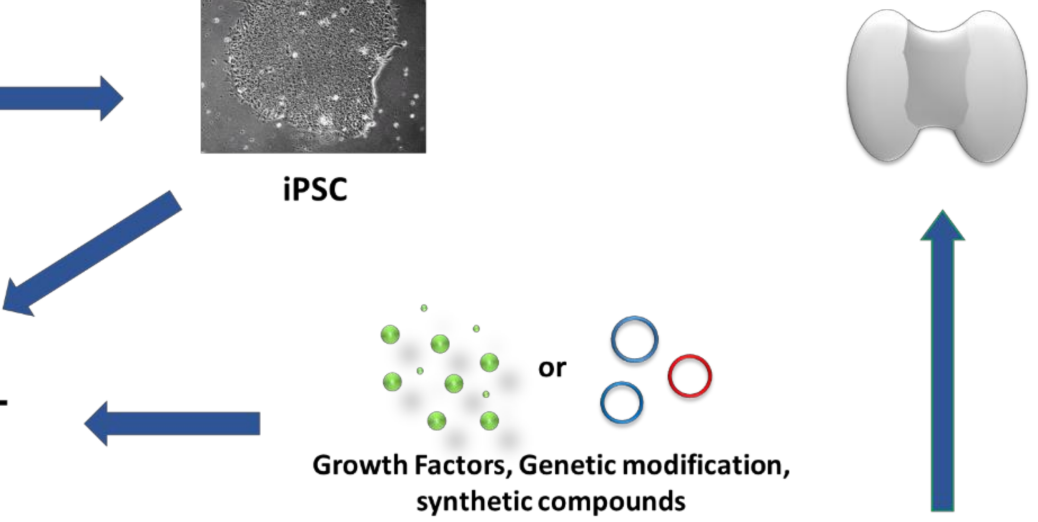
synthetic compounds

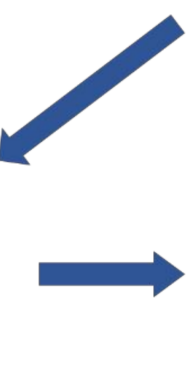

Micromasses
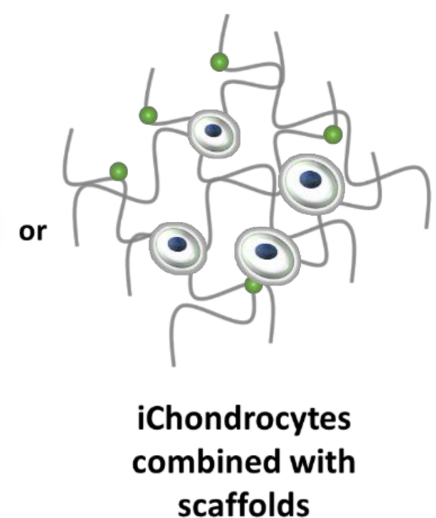

Figure 1. A schematic summarisation of the distinct approaches of iPSC chondrogenic differentiation to repair articular cartilage damage based on the current protocols. To form iPSC's allogeneic/autologous source, the first step requires the differentiation of iPSC cells into iMSC through the straightforward process or spontaneous iPSC changes into mesenchymal-like stromal cells using an embryoid body step and the additional supplementation of a growth factor to unify this process. The obtained iMSC cells also undergo chondrogenic differentiation using the most common approach through the formation of pellet culture, commonly known as the micromass technique, for some period when the cells mature and produce an appropriate amount of ECM. Other possibilities require the use of biocompatible scaffolds, which also support chondrogenic differentiation and create a ready-to-use patch for large defects in damaged cartilage or a suitable model for skeletal developmental diseases.

Table 2. The protocols of chondrogenic differentiation of iPSC cells with the best outcomes among the studied variants.

\begin{tabular}{|c|c|c|c|c|c|}
\hline System of Culture & Differentiation Factor & Duration & In Vivo Confirmation & Serum-Free & Ref. \\
\hline $\mathrm{EB} \rightarrow 3 \mathrm{D}$ PELLET & $\begin{array}{l}\text { Stage 1: Mesenchymal differentiation through } \\
\text { EB, ATRA }\left(10^{-7} \mathrm{M}\right) \\
\text { Stage 2: Chondrogenesis: alginate }(2 \%), \\
\text { TGF- } \beta 3\left(10 \mathrm{ng} \mathrm{mL}^{-1}\right)\end{array}$ & 33 days & $\begin{array}{l}\text { Yes (osteochondral defect of the knee, rat) } \\
\text { Outcome: } 12 \text { weeks after implantation, the } \\
\text { macroscopic (ICRS) and histologic evaluation } \\
\text { revealed better regenerative properties of } \\
\text { iPSC-derived chondrocytes compared to the } \\
\text { control group; Lack of teratoma formation } \\
\text { was observed }\end{array}$ & No & Ko et al., 2014 [102] \\
\hline $\mathrm{EB} \rightarrow \mathrm{MONOLAYER}$ & $\begin{array}{l}\text { Stage 1: Mesenchymal induction through EB } \\
\text { formation } \\
\text { Stage 2: Chondrogenesis: TGF- } \beta 1 \\
\left(10 \mathrm{ng} \mathrm{mL}^{-1}\right)\end{array}$ & 14 days & $\begin{array}{l}\text { Yes (osteochondral defect of the knee, rat) } \\
\text { Outcome: } 15 \text { weeks after implantation, the } \\
\text { Micro-CT images and macroscopical evaluation } \\
\text { has shown the repair of the damaged area on the } \\
\text { surface, but the subchondral trabecular bone was } \\
\text { not recovered; Histological analysis confirmed } \\
\text { neocartilage formation and expression of COL2 } \\
\text { and GAGs; Lack of teratoma development } \\
\text { was notified }\end{array}$ & No & Zhu et al., 2016 [103] \\
\hline
\end{tabular}


Table 2. Cont.

\begin{tabular}{|c|c|c|c|c|c|}
\hline System of Culture & Differentiation Factor & Duration & In Vivo Confirmation & Serum-Free & Ref. \\
\hline$\underset{\text { PELLET }}{\mathrm{EB} \rightarrow \mathrm{MONOLAYER}} \rightarrow$ 3D & $\begin{array}{l}\text { Stage 1: Collection of EB outgrowth } \\
\text { Stage 2: Chondrogenic differentiation TGF- } \beta 1 \\
\left(10 \mathrm{ng} \mathrm{mL}^{-1}\right)\end{array}$ & 48 days & $\begin{array}{l}\text { Yes (kidney capsule, mice) } \\
\text { Outcome: } 6 \text { weeks after implantation, the } \\
\text { histological analysis revealed the GAGs } \\
\text { deposition and presence of COL2 and COL10; } \\
\text { Lack of teratoma was observed }\end{array}$ & No & Li et al., 2016 [104] \\
\hline$\underset{\text { PELLET }}{\mathrm{EB}} \rightarrow \underset{\mathrm{MONOLAYER}}{\mathrm{MOND}}$ & $\begin{array}{c}\text { Stage 1: EB culture TGF- } \beta 1\left(2 \mathrm{ng} \mathrm{mL}^{-1}\right) \\
\text { Stage 2: Outgrowth of EB transfected with } \\
\text { BMP-2 or TGF- } \beta 3 \\
\text { Stage 3: BMP2 or TGF- } \beta 3 \text { transfected } \\
\text { outgrowth EB mixed equally and cultured 3D }\end{array}$ & 47 days & $\begin{array}{l}\text { Yes (osteochondral defect of the knee, rat) } \\
\text { Outcome: } 8 \text { weeks after implantation of } \\
\text { chondrogenic pellets, the damaged area was } \\
\text { restored with the tissue containing a high level of } \\
\text { GAG, COL2 and low amount of COL1 or COLL10; } \\
\text { Lack of teratoma formation was notified. }\end{array}$ & No & Rim et al., 2020 [105] \\
\hline$\underset{\text { PELLET }}{\mathrm{EB} \rightarrow \mathrm{MONOLAYER}} \rightarrow$ MD & $\begin{array}{l}\text { Stage 1: Collection of EB outgrowth } \\
\text { Stage 2: Chondrogenic differentiation TGF- } \beta 3 \\
\left(10 \mathrm{ng} \mathrm{mL}^{-1}\right)\end{array}$ & 42 days & No & No & $\begin{array}{l}\text { Koyama et al., } \\
2013[106]\end{array}$ \\
\hline$\underset{\text { PELLET }}{\mathrm{EB} \rightarrow \text { MONOLAYER }} \rightarrow$ 3D & $\begin{array}{l}\text { Stage 1: Activin A }\left(2 \mathrm{ng} \mathrm{mL}^{-1}\right) \text {; BMP-4 } \\
\left.\text { (3 ng mL } \mathrm{mL}^{-1}\right) \text {; FGF2 }\left(5 \mathrm{ng} \mathrm{mL}^{-1}\right), \text { CHIR99021 } \\
\text { Stage 2: Dorsomorphin }(4 \mu \mathrm{M}) \text {; FGF2 } \\
\left(10 \mathrm{ng} \mathrm{mL} \mathrm{m}^{-1}\right), \text { SB431542 }(5.4 \mu \mathrm{M}) \\
\text { Stage 3: TGF- } \beta 3\left(10 \mathrm{ng} \mathrm{mL}^{-1}\right)\end{array}$ & 25 days & $\begin{array}{l}\text { Yes } \\
\text { (subcutaneously, mice) } \\
\text { Outcome: } 12 \text { weeks after implantation, the } \\
\text { histological analysis of formed pellets has shown } \\
\text { high expression of COL2, GAGs and low content } \\
\text { of COL1; There was a lack of signs of } \\
\text { mineralisation or teratoma formation }\end{array}$ & Yes & Craft et al., 2015 [107] \\
\hline$\underset{\text { PELLET }}{\mathrm{EB} \rightarrow \mathrm{MONOLAYER}} \rightarrow$ 3D & $\begin{array}{l}\text { Stage 1: Mesoderm induction during EB } \\
\text { formation: WNT3A }\left(25 \mathrm{ng} \mathrm{mL}^{-1}\right), \mathrm{Activin}^{-1} \\
\left(50,25,10 \mathrm{ng} \mathrm{mL}^{-1}\right), \mathrm{FGF} 2\left(50 \mathrm{ng} \mathrm{mL}^{-1}\right) \text { and } \\
\text { BMP4 }\left(40 \mathrm{ng} \mathrm{mL}^{-1}\right) \\
\text { Stage 2: FGF2 }\left(50 \mathrm{ng} \mathrm{mL}^{-1}\right), \mathrm{BMP}^{-1}(40, \\
\left.20 \mathrm{ng} \mathrm{mL}^{-1}\right) \text {, Follistatin }\left(100 \mathrm{ng} \mathrm{mL}^{-1}\right), \mathrm{NT} 4 \\
\left(2 \mathrm{ng} \mathrm{mL}^{-1}\right) \text { and GDF5 }\left(20,40 \mathrm{ng} \mathrm{mL}^{-1}\right) \\
\text { Stage 3: IGF (N.A.), FGF2 (N.A) }\end{array}$ & 42 days & $\begin{array}{l}\text { Yes (subcutaneously, mice) } \\
\text { Outcome: } 4 \text { weeks after implantation, the } \\
\text { harvested pellet exhibited formation of cartilage } \\
\text { containing a high amount of COL2 and ECM, } \\
\text { without COL10 expression; Lack of development } \\
\text { of teratoma }\end{array}$ & No & Lee et al., 2015 [108] \\
\hline $\begin{aligned} & \text { PELLET } \rightarrow \text { MONOLAYER } \\
& \text { PELLET }\end{aligned}$ & $\begin{array}{l}\text { Stage 1: Predifferentiation TGF- } \beta 1 \\
\quad\left(10 \mathrm{ng} \mathrm{mL}^{-1}\right) \\
\text { Stage 2: Expansion (Human Serum) } \\
\text { Stage 3: maturation TGF- } \beta 1\left(10 \mathrm{ng} \mathrm{mL}^{-1}\right)\end{array}$ & 70 days & No & No & $\begin{array}{l}\text { Boreström et al., } \\
\quad 2014[109]\end{array}$ \\
\hline MONOLAYER & $\begin{array}{l}\left.\text { Stage 1: WNT3A (25 } \mathrm{ng} \mathrm{mL}^{-1}\right) \text {; Activin A } \\
\left(50,25,10 \mathrm{ng} \mathrm{mL}^{-1}\right) \text {; FGF2 }\left(20 \mathrm{ng} \mathrm{mL}^{-1}\right) ; \mathrm{BMP} 4 \\
\left(40 \mathrm{ng} \mathrm{mL}^{-1}\right) \text {; Follistatin }\left(100 \mathrm{ng} \mathrm{mL}^{-1}\right) \\
\left.\text { Stage 2: BMP4 (40 } \mathrm{ng} \mathrm{mL}^{-1}\right) \text {; FGF2 }(20 \mathrm{ng} \\
\left.\mathrm{mL}^{-1}\right) ; \text { GDF-5 }\left(40 \mathrm{ng} \mathrm{mL}^{-1}\right)\end{array}$ & 14 days & No & Yes & Yang et al., 2012 [110] \\
\hline MONOLAYER $\rightarrow 3$ D DISK & 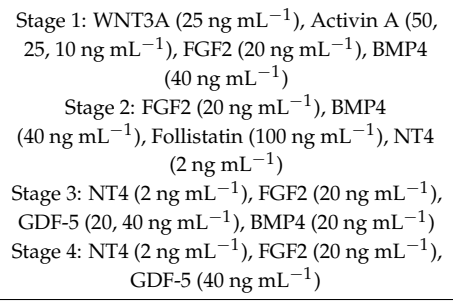 & 21 days & $\begin{array}{l}\text { Yes (osteochondral defect, mice) } \\
\text { Outcome: } 8 \text { and } 16 \text { weeks after transplantation, } \\
\text { the newly formed cartilage tissue was observed } \\
\text { with dense ECM; one of the tested subjects has } \\
\text { developed the teratoma }\end{array}$ & Yes & Saito et al., 2015 [111] \\
\hline $\begin{array}{l}\text { MONOLAYER } \rightarrow \text { 3D } \\
\text { PELLET }\end{array}$ & $\begin{array}{l}\text { Stage 1: Mesoendodermal induction: WNT3A } \\
\quad\left(10 \mathrm{ng} \mathrm{mL}^{-1}\right) \text {, Activin A }\left(10 \mathrm{ng} \mathrm{mL}^{-1}\right) \\
\text { Stage 2: Chondrogenesis: BMP2 }\left(10 \mathrm{ng} \mathrm{mL}^{-1}\right) \text {, } \\
\text { TGF- } \beta 1\left(10 \mathrm{ng} \mathrm{mL}^{-1}\right) \text {, GDF5 }\left(10 \mathrm{ng} \mathrm{mL}^{-1}\right)\end{array}$ & 42 days & $\begin{array}{c}\text { Yes (subcutaneously, mice; } \\
\text { Osteochondral defect, rat; } \\
\text { Osteochondral defect, mini pig) } \\
\text { Outcome: In mice, after } 12 \text { weeks, the implanted } \\
\text { spheres exhibited microscopical morphology of } \\
\text { hyaline cartilage with high ECM deposition and } \\
\text { high COL2 expression; After } 12 \text { months, the } \\
\text { implanted pellets underwent hypertrophy and } \\
\text { maintained epiphyseal morphology; In rats, after } \\
4 \text { weeks, the osteochondral defect was restored } \\
\text { with cartilage tissue expressing high COL2 and } \\
\text { high GAG content with good integration with } \\
\text { surrounding tissue; In mini-pigs, after } 4 \text { weeks the } \\
\text { damaged cartilage was restored with visible } \\
\text { integration with host tissue; Lack of teratoma } \\
\text { formation in tested subjects }\end{array}$ & No & $\begin{array}{l}\text { Yamashita et al., } \\
\quad 2015 \text { [112] }\end{array}$ \\
\hline MONOLAYER & $\begin{array}{c}\text { Stage 1: Mesoendoderm CHIR99021 }(10 \mu \mathrm{M}) \\
\text { and TTNPB }(100 \mathrm{nM}) \\
\text { Stage 2: Chondrogenesis TTNPB }(100 \mathrm{nM})\end{array}$ & 9 days & $\begin{array}{c}\text { Yes (subcutaneously, mice; osteochondral defect } \\
\text { of the knee, mice) } \\
\text { Outcome: After } 8 \text { weeks, histological analysis of } \\
\text { subcutaneously implanted disc revealed high } \\
\text { ECM and COL2 deposition without COL10 } \\
\text { expression; After } 6 \text { months, histological analysis } \\
\text { of the knee revealed the formation of hyaline } \\
\text { cartilage enriched in COL2, ECM, and lack of } \\
\text { COL10; Lack of teratoma was notified; The } \\
\text { histological score was better than in the } \\
\text { treated group. }\end{array}$ & Yes & $\begin{array}{l}\text { Kawakata et al., } \\
\quad 2019[113]\end{array}$ \\
\hline$\underset{\text { PELLET }}{\text { MONOLAYER }} \rightarrow 3 \mathrm{D}$ & $\begin{array}{l}\text { Stage 1: CHIR99021 }(5 \mu \mathrm{M}) \text {, FGF2 }\left(4 \mathrm{ng} \mathrm{mL}^{-1}\right) \\
\text { Stage 2: TGF- } \beta 1\left(10 \mathrm{ng} \mathrm{mL}^{-1}\right)\end{array}$ & 56 days & No & No & $\begin{array}{l}\text { Kreuser et al., } \\
2020[114]\end{array}$ \\
\hline
\end{tabular}


Table 2. Cont.

\begin{tabular}{|c|c|c|c|c|c|}
\hline System of Culture & Differentiation Factor & Duration & In Vivo Confirmation & Serum-Free & Ref. \\
\hline $\begin{array}{l}\text { MONOLAYER } \rightarrow 3 \mathrm{D} \\
\text { PELLET }\end{array}$ & $\begin{array}{c}\text { Stage 1: Mesodermal lineage induction: Activin } \\
\left.\text { A (30 ng mL } \mathrm{m}^{-1}\right), \text { SB505124 }(2 \mu \mathrm{M}), \text { CHIR99021 } \\
(4,3 \mu \mathrm{M}), \text { FGF2 }\left(20 \mathrm{ng} \mathrm{mL}^{-1}\right), \mathrm{C} 59(1 \mu \mathrm{M}), \\
\text { Dorsomorphin }(4 \mu \mathrm{M}), \text { PD173074 }(500 \mathrm{nM}), \\
\text { Purmorphamine }(1 \mu \mathrm{M}) \\
\text { Stage 2: Prechondrogenesis: BMP4 } \\
\left(20 \mathrm{ng} \mathrm{mL}^{-1}\right) \\
\text { Stage 3: Chondrogenesis: TGF- } \beta 3 \\
\left(10 \mathrm{ng} \mathrm{mL}^{-1}\right)\end{array}$ & 43 days & No & Yes & Adkar et al., 2019 [115] \\
\hline $\begin{array}{l}\text { MONOLAYER } \rightarrow 3 \mathrm{D} \\
\text { PELLET }\end{array}$ & $\begin{array}{c}\text { Stage 1: Mesenchymal induction through } \\
\text { spontaneous differentiation, FGF2 }\left(5 \mathrm{ng} \mathrm{mL}^{-1}\right) \\
\text { Stage 2: Chondrogenic differentiation BMP2 } \\
\left(100 \mathrm{ng} \mathrm{mL}^{-1}\right)\end{array}$ & 50 days & No & No & Guzzo et al., 2013 [116] \\
\hline $\begin{array}{l}\text { MONOLAYER } \rightarrow 3 \mathrm{D} \\
\text { PELLET }\end{array}$ & $\begin{array}{l}\text { Stage 1: MSC induction spontaneous } \\
\text { differentiation } \\
\text { Stage 2: Chondrogenic differentiation TGF- } \beta 3 \\
\left(10 \mathrm{ng} \mathrm{m}^{-1}\right)\end{array}$ & 56 days & $\begin{array}{c}\text { Yes } \\
\text { (Osteochondral defect of the knee, rat) } \\
\text { Outcome: After } 6 \text { weeks, the implanted spheres } \\
\text { have shown good integration with the } \\
\text { surrounding tissue, increased GAG and COL2 } \\
\text { expression; The ICRS score was the highest in the } \\
\text { iPS-derived chondrocytes }\end{array}$ & No & $\begin{array}{l}\text { Nejadnik et al., } \\
2015 \text { [117] }\end{array}$ \\
\hline $\begin{array}{l}\text { MONOLAYER } \rightarrow 3 \mathrm{D} \\
\text { PELLET }\end{array}$ & $\begin{array}{l}\text { Stage 1: mesenchymal progenitor induction } \\
\left.\text { FGF ( } 4 \mathrm{ng} \mathrm{mL}^{-1}\right) \\
\text { Stage 2: Chondrogenesis TGF- } \beta 1\left(10 \mathrm{ng} \mathrm{mL}^{-1}\right) \\
\text { and BMP4 }\left(100 \mathrm{ng} \mathrm{mL}^{-1}\right)\end{array}$ & 70 days & No & No & $\begin{array}{l}\text { Diederichs et al., } \\
2016[118]\end{array}$ \\
\hline $\begin{array}{l}\text { MONOLAYER } \rightarrow 3 \mathrm{D} \\
\text { PELLET }\end{array}$ & $\begin{array}{l}\text { Stage 1: mesenchymal differentiation: FGF } \\
\left.\text { (4 ng mL } \mathrm{m}^{-1}\right) \\
\text { Stage 2: Chondrogenesis: TGF- } \beta 1 \\
\left(10 \mathrm{ng} \mathrm{mL}^{-1}\right)\end{array}$ & 42 days & No & No & $\begin{array}{l}\text { Diederichs et al., } \\
2019[119]\end{array}$ \\
\hline MONOLAYER & $\begin{array}{l}\text { Stage 1: Spontaneous differentiation into MSC } \\
\quad \text { in low glucose DMEM } \\
\text { Stage 2: Chondrogenesis TGF- } \beta 1\left(10 \mathrm{ng} \mathrm{mL}^{-1}\right)\end{array}$ & 49 days & $\begin{array}{l}\text { Yes (osteochondral defect of the knee, rabbit) } \\
\text { Outcome: After } 12 \text { weeks, histological analysis } \\
\text { revealed better microscopical integration, } \\
\text { increased ICRS score, higher aggrecan content } \\
\text { and better regeneration than the control group; } \\
\text { lack of teratoma formation }\end{array}$ & No & Chang et al., 2020 [120] \\
\hline $\begin{array}{l}\text { MONOLAYER } \rightarrow 3 \mathrm{D} \\
\text { HYDROGELS }\end{array}$ & $\begin{array}{l}\text { Stage 1: Mesenchymal induction through } \\
\text { spontaneous differentiation, FGF2 }\left(5 \mathrm{ng} \mathrm{mL}^{-1}\right) \\
\text { Stage 2: Chondrogenic differentiation in the } \\
\text { presence of TGF- } \beta 3\left(10 \mathrm{ng} \mathrm{mL}^{-1}\right) \text { and } \\
\text { mechanical loading }\end{array}$ & 50 days & No & No & $\begin{array}{l}\text { Aisenbrey et al., } \\
2019 \text { [121] }\end{array}$ \\
\hline 3D PELLET & $\begin{array}{c}\text { Extracts from Li2C4S4 bioceramic }(12.5,6.25 \\
\left.3.125 \mathrm{mg} \mathrm{mL}^{-1}\right) \text { in commercial } \\
\mathrm{MCDM} \text { medium }\end{array}$ & 14 days & No & Yes & Hu et al., 2020 [122] \\
\hline MONOLAYER(HYALURONAN) & $\begin{array}{l}\text { Co-culture with primary bovine chondrocytes, } \\
\text { TGF- } \beta 3\left(10 \mathrm{ng} \mathrm{mL}^{-1}\right)\end{array}$ & 21 days & No & No & Qu et al., 2013 [123] \\
\hline $\begin{array}{l}\text { MONOLAYER } \\
\text { (SCAFFOLDS) }\end{array}$ & $\begin{array}{l}\text { iPSC transduced with TGF- } \beta 1 \text { and co-culture } \\
\text { with chondrocytes }\end{array}$ & 14 days & $\begin{array}{c}\text { Yes } \\
\text { (Subcutaneously, mice) } \\
\text { Outcome: After } 6 \text { weeks, histological analysis } \\
\text { confirmed the highest expression of COL2 and } \\
\text { formation of lacuna in TGF- } \beta 1 \text { / Alginate } \\
\text { compared to other variants; lack of } \\
\text { teratoma formation }\end{array}$ & No & Wei et al., 2012 [124] \\
\hline
\end{tabular}

ATRA: all-trans retinoic acid; BMP2: Bone Morphogenetic Protein 2; BMP4: Bone Morphogenetic Protein 4; C59: 2-(4-(2-methylpyridin-4-yl)phenyl)-N-(4-(pyridin-3-yl)phenyl)acetamide; CHIR99021: 6-2-4-(2,4-dichlorophenyl)5-(5-methyl-1H-imidazol-2-yl)-2-pyrimidinylaminoethylamino-3-pyridinecarbonitrile; COL2: type II collagen; COL10: type X collagen; DMEM: Dulbecco's Modified Eagle's Medium; EB: embryoid bodies; ECM: extracellular matrix; FGF2: Fibroblasts Growth Factor 2; GAG: glycosaminoglycans; GDF5: Growth Differentiation Factor 5; ICRS: International Cartilage Repair Society; MCDM: mesenchymal stem cell chondrogenic medium MSC: mesenchymal stromal cell; NT4: Neurotrophin-4; PD173074: N-2-4-(diethylamino)butylamino-6-(3,5dimethoxyphenyl)pyrido2,3-dpyrimidin-7-yl-N'-(1,1-dimethylethyl)urea; SB505124: 2-(5-benzo1,3dioxol-5-yl-2tert-butyl-3H-imidazol-4-yl)-6-methylpyridine hydrochloride hydrate; TGF- $\beta 1$ : transforming growth factor $\beta 1$; TGF- $\beta 3$ : transforming growth factor $\beta 3$; TTNPB: 4-[(E)-2-(5,6,7,8-tetrahydro-5,5,8,8-tetramethyl-2-naphthalenyl)1-propenyl]benzoic acid; WNT3A: Wingless/Int1 family member 3a.

\subsection{Differentiation Methods Using Embryoid Bodies (EB)}

Embryoid bodies are three-dimensional aggregates of PSC that may be used to obtain three germ layer cells due to their natural properties. The various methods for obtaining EBs were developed, such as a liquid suspension culture in bacterial-grade dishes, a culture in methylcellulose semisolid media, and a culture in hanging drops (HD culture) or even 3D-printed controllable wells of the desired size, which is crucial for this process to maintain a homogenous size and sphericity [125-130]. This is a crucial step, because microenvironmental cell culture factors such as oxygenation of the aggregates, access to nutrients, or even a concentration of endogenous growth factors may lead to less efficient differentiation potential into the desired germ layer by the activation of distinct signalling pathways 
determining their fate [131-133]. However, this approach is still popular among scientists, because it is one of the easiest methods of inducing PSC spontaneous differentiation with some control over their fate [125].

Several studies regarding chondrogenic differentiation used that approach with some success (Table 2). The Ko team used that protocol to compare the chondrogenic potential of iPSC with human BMMSC in the regeneration of a knee defect [102]. The EBs formed were dissociated and differentiated into alginate spheres for three weeks in the presence of TGF- $\beta 3$, known as one of the most pro-chondrogenic growth factors [134]. They have confirmed that iChondrocytes had a higher expression of chondrogenic markers and better regenerative potential than hBMMSC differentiated in the same regimen [102]. Another protocol based on the EB formation step was developed by Zhu et al. [103]. Surprisingly, they repaired a rat's knee defect in 15 weeks by implanting EB sprouts that had undergone only two weeks' differentiation in a gelatin monolayer with TGF- $\beta 1$. COL2 staining, however, was not quite as intense as observed in the surrounding tissue, but at some point, regeneration of the surface occurred in the chemically induced OA (using monosodium iodoacetate) in comparison with the control [103]. An attractive solution was proposed by $\mathrm{Li}$ et al. where, for the production of iPSC cells, the peripheral mononuclear cells (PBMC) were reprogrammed using episomal vectors [104]. This allows them to obtain many cells with a less invasive collection method, and besides a low efficiency, a safe source of cells for regenerative medicine purposes was produced [72,104,135]. To improve the chondrogenic potential, after an EB monolayer culture, the cells were also sorted using two positive mesenchymal markers: $\mathrm{CD}_{3}{ }^{+}$and $\mathrm{CD}_{105}{ }^{+}$, enhancing the homogeneity of the cell culture. The 3D in vitro and in vivo differentiation indicated significantly increased expression of chondrogenic markers such as COL2, COL9, and AGGRECAN with a high proteoglycans deposition on a comparable level with chondrogenic pellets obtained from MSC [104].

Rim and Nam's team have published a few interesting papers regarding reprogramming cord blood mononuclear cells (CBMC) for cartilage regeneration $[105,136]$. Their low immunogenic nature and broad access due to biobanking mean they are likely to be an attractive source of cells for the allogeneic transplantation to treat large cartilage defects. This team developed a chondrogenic protocol based on EB outgrowth cells cultured on gelatin-covered plates and passaged several times, which generated MSC-like cells suitable for differentiation towards chondrocytes in the presence of BMP2 and TGF- $\beta 3$, a combination that enhances chondrogenic differentiation better than their separate supplementation [137]. However, the addition of several growth factors significantly increases the cost of a cell culture. Therefore, this team of researchers proposed a solution based on the transfection of the EB outgrowth of cells with minicircle vectors encoding BMP2 or TGF- $\beta 3$ and mixing both populations [105]. This combination resulted in efficient differentiation with a good outcome regarding the repair of osteochondral defects with reduced costs of a cell culture [105].

Another simple protocol was established by the Koyama team, where, using EB outgrowth, they received MSC-like cells and, further, chondrogenically differentiated them into 3D pellets in the presence of TGF- $\beta 3$. The formed pellets exhibited a weak expression of COL2 and aggrecan production, indicating the early stages of chondrogenesis [106]. They suggested that using additional growth factors, mechanical forces, or a hypoxic cell culture may enhance the maturation and deposition of ECM characteristics for mature hyaline cartilage $[138,139]$. The authors, however, failed to confirm the in vivo maturation of the derived cells, but their protocol was reproducible in several hiPSC and hESC cell lines, which may be used for disease modelling related to skeletal abnormalities.

The Crafts team proposed a more advanced protocol, which discovered the stable differentiation of iPSC cells using a few events mimicking embryogenesis. Firstly, they induced primitive streak mesoderm $\left(\mathrm{CD}^{+} 6^{+} \mathrm{KDR}^{+} \mathrm{PDGFR} \alpha^{+}\right)$using the EB approach with exposure to activin A, BMP4, and FGF2; further into a paraxial mesoderm $\left(\mathrm{CD} 73^{+} \mathrm{CD} 105^{+} \mathrm{PDGFR} \beta^{+}\right)$ using dorsomorphin; and finally, into chondroprogenitors in the presence of TGF- $\beta 3$ or BMP4. They established that BMP4 micromasses tend to undergo endochondral ossification 
by the increased expression of hypertrophic markers rather than with TGF- $\beta 3$-treated cells. The implanted micromasses indicated a stable chondrogenic phenotype for over 12 weeks after subcutaneous implantation. It was also one of the first protocols of iPSC cultured in serum-free conditions, which implies its preclinical potential [107].

In the same year, Lee's team presented another suitable protocol based on Oldershaw et al. with a few modifications $[99,108]$. In the early stages, instead of a monolayer culture, an EB approach with the supplementation of a ROCK inhibitor (Y27632) was used, resulting in the increased viability of cells and the enhanced chondrogenic potential of differentiated cells by a high number of SOX9-positive cells. They exhibited an expression of WNT9A and SOSTCD1 characteristics for ACC from the interzonal part of the histological structure of joint cartilage. After two passages, they matured, which was notified by the presence of a stable and homogenous positive population for SOX $9{ }^{\text {high }} \mathrm{CD} 44^{\text {high }} \mathrm{CD} 140^{\text {high }}$, a marker related to advanced chondrogenesis. They also showed that the $3 \mathrm{D}$ culture and in vivo subcutaneous xenotransplantation formed hyaline cartilage without visible pathological changes suggesting tumorigenesis, which support the safety of that protocol.

Boreström's team, meanwhile, demonstrated that human chondrocytes might be reprogrammed safely with synthetic mRNA and redifferentiated into chondrogenic cells. The first step of the induction of chondrogenesis was unexpectedly related to the culture of a massive cell pellet culture $\left(4 \times 10^{5}\right.$ cells $)$ in the chondrogenic medium in the presence of TGF- $\beta 1$. The cells were then removed from spheres and expanded for another 14 days in the presence of human serum and, finally, re-pelleted and cultured for another 35 days in the chondrogenic medium from the first step. The limited use of growth factors combined with a lengthy cell culture resulted in spheres expressing high levels of ECM but lower levels of COL2 after differentiation than chondrogenic spheres obtained from donor chondrocytes. However, the lack of in vivo testing did not confirm their utility. Besides the low expression of type II collagen, the spheres expressed comparable type X collagen with donor chondrogenic pellets, which may be explained by the epigenetic memory of OA chondrocytes used in reprogramming.

\subsection{Direct Methods for Obtaining Chondrocytes from iPSCs}

Another part of this review is focused on the monolayer approach, which is more popular than the methods that include the EB step (Table 2). These protocols, however, require the additional supplementation of growth factors and ECM-coating plates, increasing the general costs of stem cell differentiation. However, one great benefit is that this creates a more controllable environment in which to reproduce many cells with a homogenous phenotype than in approaches based on EBs. As mentioned above, their derivation and spontaneous differentiation depend significantly on the cellular mass and culture-well shape. Consequently, a heterogenous population among the derived cells is observed, which requires extra selection steps to obtain a homogenous population. Recent years have brought a tremendous update regarding chondrogenic differentiation protocols with good outcomes, which has created a new platform for anti-OA drug development and studies of chondrogenesis and their pathologies.

The Yang team developed a protocol that modified the Oldershaw et al. approach [110]. They created a simple version of that protocol for drug screening purposes. During differentiation of the keratinocyte-derived iPS cells, they limited the usage of growth factors (NT4 excluded from the protocol), to passage only once in seven days and cultured for another seven days. The plates were also coated with Matrigel alone and optimised for the 96-well format. That simplified and chemically defined protocol has established its suitability for drug testing on the example of two novel peptides, AB235 and NB61, which are new classes of high-affinity TGF- $\beta$ family ligands [140]. Notwithstanding this, Oldershaw's and Yang's protocols are sufficiently fast, but they have some limitations regarding tumorigenesis, as Saito's group study showed. It was modified to prolong the time for the cell culture for another week (21 days in total) to form the chondrogenic disc, ready to use in the place of cartilage depletion. Sixteen weeks after transplantation, one 
of the differentiated clones in the implanted knee of the SCID mice developed a teratoma from the remnants of iPSC in the delivered construct. The changes were not observed eight weeks after implantation, suggesting the importance of long-term studies and strict safety procedures regarding tissues formed from iPSC and their genetic stability [64,111].

Yamashita's team developed a promising protocol of chondrogenic differentiation with colossal potential for producing large cartilage-like particles [112]. The researchers emphasised that the application of BMP2, TGF- $\beta 1$, and GDF5 factors was essential for the chondrogenic differentiation of hiPSC-derived mesenchymal cells. They also pointed out that the environmental factor and appropriate timing of implantation spheres are crucial to their in vivo maturation. Yamashita's researchers also developed an efficient way to differentiate hiPSCs into chondrocytes without using scaffolds and embryoid bodies with good repair properties [112]. They also recently indicated the ability of their chondrogenic cells to integrate with the surrounding tissue and itself, which is crucial for maintaining an intact joint surface with the limited progression of OA. They also discovered that FGF-18 was a growth factor secreted by a perichondrium-like membrane, responsible for the ability of obtained cartilage-like particles to integrate [141].

Another way to obtain chondrocytes directly is by using small-molecule compounds. The protocol invented by the Kawata team was the fastest: it took only nine days to obtain chondrogeniclike cells [113]. Their approach was based on using CHIR99021 (6-((2-((4-(2,4-Dichlorophenyl)-5-(4methyl-1H-imidazole-2-yl)pyrimidine-yl)amino)ethyl)amino)nicotinonitrile) and TTNPB (4-[(E)-2(5,6,7,8-Tetrahydro-5,5,8,8-tetramethyl-2-naphthalene)-1-propenyl]benzoic acid) [113]. CHIIR99021 is a chemical compound that acts as an inhibitor of GSK3 (glycogen synthase kinase 3), responsible for the regulation of the WNT signalling pathway, and mainly causes cell differentiation into the mesoderm [115], TTNPB, meanwhile, otherwise known as arotinoid acid, belongs to the retinoid acid receptor (RAR) antagonist, which plays an important role at the early stages of the formation of limb buds [113,142]. The proposed combination of these two compounds in serum-free conditions resulted in differentiation into chondrogenic-like cells without remnants of pluripotent cells. Their subcutaneous implantation revealed the formation of hyaline cartilage. The 6-month observation of the implanted cells into knee defects in mice also revealed the formation of functional cartilage without the notification of teratoma or tumour formation, supporting the safety of this approach [113]. A similar usage of CHIR99021 was proposed by Kreuser's team, who revealed that its short administration, no more than $24 \mathrm{~h}$, significantly increases the efficiency of chondrogenic differentiation by improving mesoderm aggregation and condensation, a crucial process during the formation of cartilage nodules [114]. This chemical molecule caused the increased proliferation of cells and the formation of bigger cartilage-like pellets with a dense deposition of ECM compared to the controlled population, leading to a higher number of cells suitable for the coverage of large defects.

A more complex and controllable protocol was proposed recently by the Adkar team, in which they used a cocktail of cytokines and chemical molecules (Table 2), which enabled the highest control of the differentiation process by the regulation of all the developmental stages from pluripotent to sclerotome formation within three days [115]. Besides obtaining a pure population of the early chondrogenic population, in vitro maturation has shown some histological heterogeneity. The authors, therefore, created the reporter cell lines dependent on the expression level of COL2A1. The sorted population exhibited homogenous cartilaginous spheres with stable phenotypes through several passages. Besides the lack of in vivo assays, the in vitro spheres exhibited a high ECM deposition with intense COL2 staining without the presence of hypertrophy or calcifications, which suggests their potency in the regeneration of hyaline cartilage lesions.

Another protocol worth mentioning was proposed by the Guzzo team, which, while not ideal, served as a basic protocol to be adapted by other teams [116,117]. Briefly, they derived the MSC-like cells by spontaneous differentiation via the passaging of iPSC cells in DMEM with FBS and FGF2 until a homogenous population of cells with a spindle-like shape was produced. The morphological changes were intact with their flow cytometric analysis, which revealed the acquiring of BMMSC-like cells with the ability to differentiate 
into chondrogenic cells in the presence of BMP2 [116]. A similar protocol was proposed by Nejadnik's team [117]. In their method, iPSC cells were primarily cultivated in the basic medium without FGF on Matrigel-coated plates (for five days) and then transferred onto an uncoated cell culture dish. The differentiated cells exhibited the morphology of MSC cells and characteristic expression of the proteins according to the International Society for Cell Therapy guidelines. Chondrogenically differentiated cells in the 3D pellet with TGF- $\beta 3$ were then implanted into osteochondral defects of the distal femurs of rats. MRI imaging and a histological analysis revealed a lack of teratoma formation with a good coverage of cartilage depletion. This approach exhibited a slight expression of fibrocartilage and hypertrophic markers, however, which would represent an unacceptable long-term solution, and the authors suggested further improvements of this protocol. One explanation may be related to the basal expression of SOX9 in the derived iMSC, which was shown as a crucial aspect of chondrogenic studies in a number of the Diederich team's protocols [118,119]. They found that iMSC derived by distinct methods (through EB or spontaneous or BMMSC-conditioned mediums) from the same donor has slightly different global gene expression patterns and affects their functionality compared to parental BMMSC [143]. In the case of chondrogenic differentiation, at their first approach, they observed that a low level of SOX9 expression in MSC-like cells derived from iPSC determines their chondrogenic commitment. Its expression could be partially enhanced by using a combination of TGF- $\beta 1$ and BMP4, but the in vitro differentiated spheres exhibited the expression of hypertrophic markers. BMP4 induced that effect, so, in their latest protocol, they only used TGF- $\beta 1$ [119]. Increased reproducibility was also achieved by the usage of cells with a high level of SOX9. They also indicated that cartilage spheres derived from these cells were more resistant to mineralisation than MSC. This led to the conclusion that the derived cells had undergone rejuvenation. A similar observation was noted in the Chang team, which analysed iChondrocytes obtained in comparable conditions in a rabbit model. The researchers demonstrated that the differentiated chondrocytes effectively repaired cartilage defects in vivo and indicated a downregulation of catabolic and proinflammatory cytokines [120]. The possible explanations for this phenomenon were related to the rejuvenation of cells during differentiation and, also, the confirmation of their MSC nature, which is known for its suppressive and protective properties [88].

Another approach was presented by the Aisenbrey team, which was based on the Guzzo approach [121]. They tested the hypothesis of a combination of chemical (growth factors TGF- $\beta 3$ or BMP2) and physical factors on iMSC differentiation immersed in a nondegradable hydrogel. The hydrogel consisted of multi-arm PEG norbornene macromers, PEG dithiol crosslinkers, and ECM analogues of thiolated chondroitin sulphate. The study established that the highest efficiency was achieved when the culture was performed on hydrogel scaffolds in the presence of TGF- $\beta 3$ under dynamic mechanical stimulation. The method developed was effective in both promoting chondrogenesis and simultaneously reducing hypertrophy. The researchers emphasised that additional research is needed on a degradable cartilage-like hydrogel to gain significant clinical value [121]. Another recently developed quick method was based on bioceramic products that contained lithium: $\mathrm{Li}_{2} \mathrm{Ca}_{4} \mathrm{Si}_{4} \mathrm{O}_{13}$ (L2C4S4) [122]. Lithium itself is a cheap WNT agonist that displays prochondrogenic properties during the differentiation of MSC $[144,145]$. The culture of iPSC in L2C4S4 (3.125-12.5 mg/mL) in the commercially available serum-free chondrogenic medium for 14 days caused successful chondrogenic differentiation with a high expression of chondrogenic markers, i.e., COL2, SOX9, aggrecan, and a low expression of hypertrophic markers (COL10 and MMP13). The extracts of the lithium compounds were shown to have promoted the formation of well-formed spheres, suggesting that L2C4S4 could help maintain the morphology of iPSC-derived chondrocyte spheres. This study confirmed that the action of independent $\mathrm{Li}^{+}$ions at different concentrations could also support the differentiation of iPSCs in chondrocytes and further prevent their hypertrophy. In conclusion, the scaffolds presented helped maintain the appropriate shape and volume of iPSC-derived chondrocyte spheres and supported the rapid conversion of iPSCs into 
mature chondrocytes [122]. There is, however, a lack of in vivo assays to confirm their ability to repair defects.

One the interesting ideas of differentiation iPSC towards chondrogenic-like populations of cells is the, being cocultured with chondrocytes via culture inserts, as presented by $\mathrm{Qu}$ et al. [123]. The advantage of cocultured cells in the well inserts is that the autocrine and paracrine factors secreted by one cell may readily be used and limit the labware's usage to prepare the conditioned medium itself [146]. The cells exhibited typical chondrogenic markers and a lack of pluripotent cells. After four weeks of pellet culture, they formed homogenous cartilaginous spheres that clearly expressed COL2 and ECM deposition, especially of cells cultured on hyaluronan rather than on gelatin-coated plates. Their monolayer culture through several passages also revealed a similar behaviour as a culture of naïve chondrocytes, which was observed by a decrease in the expression of COL2 with the simultaneous elevation of COL1, which is a common problem in monolayer cultures of primary chondrocytes. Along with these promising results, this study had some drawbacks. Firstly, the coculture of human iPSC cells was conducted in the presence of bovine primary chondrocytes, which could increase the risk of a possible transfer of zoonotic diseases and exclude them from clinical use. Another was related to the lack of confirmation of the expression of hypertrophic markers, but in return, they tested the ability of the cells obtained to differentiate into adipogenic or osteogenic cell populations. Mineralisation has not occurred in iPSC-derived cocultured chondrocytes, unlike MSC cells exposed to these conditions, suggesting their reduced ability to undergo hypertrophy [123].

Using human cells in a similar approach, the Wei team has differentiated reprogrammed OA chondrocytes into chondrogenic-like cells [124]. In this study, to limit the supplementation of growth factors, the authors decided to transduce iPSCs with transforming growth factor- $\beta 1$. To maintain their stable phenotype, they also used alginate-coated inserts, a natural polymer with documented pro-chondrogenic properties [147]. The combination of these factors resulted in the increased expression of hyaline cartilage marker COL2 in in vitro and in vivo models compared to non-transfected or iPSC cells cultured without improvement. This study gave rise to an intriguing observation: VEGF expression persisted in the differentiating iPSC alone and transduced with TGF- $\beta 1$, which could be related to the epigenetic memory of OA chondrocytes, since this marker is connected to advanced stages of the differentiation of chondrocytes. However, its expression was inhibited in the presence of a coculture system. The authors suggested that the phenomenon may be linked to the presence of endogenous inhibitors of angiogenesis secreted by cocultured chondrocytes [124,148].

\section{The Future-Clinical Use}

Over a decade, several protocols with satisfactory efficiency, including in vivo characterisation, were established without further application in the clinic. Clinical trials using iPSC in regenerating damaged tissues have been recently used in an example of age-related macular degeneration (AMD) restoration or neural damage $[149,150]$. In the case of musculoskeletal diseases, there is still a lack of their common usage. One reason is the lack of a well-established, unified differentiation protocol for their derivation with GMP standards [151]. Some protocols still rely on animal components such as foetal bovine serum and feeder cells. This could result in a variation of culture conditions and a risk of the transmission of zoonotic diseases, as well as ethical issues [152,153]. Moreover, the usage of serum in a chondrogenic cell culture has a negative impact on the differentiation process $[154,155]$. Another problem relates to the source of the cell for chondrogenic differentiation. Several studies have indicated that using a cell from the same donor could also influence the efficiency of chondrogenic differentiation, and the derivation of iMSC cells also revealed that they could not be equally compared to those derived from bone marrow $[143,156]$.

A few issues were not entirely solved in the proposed protocols. One of them is related to teratoma formation. A few protocols have shown that they did not observe any 
formation of teratoma in the in vivo models, and the expression of pluripotent markers was not present in the neocartilage or iChondrocytes, but in Saito et al.'s study, despite that fact, some of the cells remained, and in one tested subject, they observed the formation of a tumour [111]. However, to improve that outcome, the usage of PluriSln, a synthetic inhibitor of SCD1, could deplete the remnant PSC cells. It was already tested during the chondrogenic differentiation of hESC with a good outcome and lack of cytotoxic effect to the chondroprogenitors $[93,157]$. Another possibility, published recently, was related to the direct usage of antibodies, highly selective for iPSC, which enabled eradicating them without the affection of mature chondrocytes [94]. There are some common doubts related to the usage of iPSC cells in regenerative medicine due to their potential immune responses $[69,70]$. Cartilage itself is a tissue with low immunogenic potential due to the lack of vascularity, a high amount of dense ECM disabling the penetration of the immune cells. Moreover, the usage of scaffolds in the implantation site or large cartilage particles with dense ECM could limit the rejection of newly formed tissue $[158,159]$. Using iPSC technology, the immune response could be omitted if the cells are derived from the same patient, but due to the vast costs of reprogramming and set of assays confirming their safety, the usage of universal haplotyping biobanks could resolve that issue, decreasing the cost of the procedure $[160,161]$.

A few well-described protocols with rather good outcomes have been developed. However, Yamashita's group established one of the most promising protocols with the best combination of growth factors (TGF- $\beta 1$, GDF-5, and BMP2). Their findings have been supported by several papers describing their approach as safe and reproducible, with immunogenicity similar to native chondrocytes; they have long-lasting observations without the notification of teratoma formation and good regeneration properties in large animals with mid-sized defects (mini-pig model), and importantly, their construct is scaffoldless $[112,159,162,163]$. These findings suggest that distinct routes for obtaining iChondrocytes for regenerative purposes are possible. The variability of the protocols with quite good outcomes will enable their adaptation and everyday use, dependent on the economic status of orthopaedic centres. The new source of cells could replace the autologous chondrocytes in the standard techniques, such as MACI, where their combination with the approved by the FDA commonly used collagen matrix could decrease the time to make this solution for common use [164]. This could be a game-changer, because the chondrogenic cells obtained from iPSC also seem to be more resistant to hypertrophy due to their rejuvenation, and the procedure could be reduced to one surgery, diminishing the costs and the patient's discomfort.

\section{Disease Modelling from Chondrogenic iPSC}

Despite the lack of the use of existing differentiation protocols in the clinic, their establishment could be used in another practical way: the design of disease models regarding limb development. Developmental biology and the usage of iPSC in this well-known process could provide an insight into pathological conditions, leading to better diagnostics and the development of drug screening platforms for those diseases. One of the problems with modelling the diseases is obtaining sufficient tissue for analysis. This involves invasive procedures and general discomfort for the patient and a reduced quality of life for the patients, especially children and young adolescents [165-167]. Obtaining PBMC or dermal fibroblasts is less controversial in testing and formation modelling diseases, especially involving limb development. Patient-specific derived tissues enable matching the appropriate treatment regimen and doses of potential drugs. It may also eliminate the usage of animal testing, since their physiology and response to the treatment is unlike that in human physiology [168]. The specimens of skeletal abnormalities are difficult to collect because of cartilage's limited healing ability and may be invasive for the tested patient. Table 3 summarises the distinct models of diseases and iPSC derived from patients with specific mutations related to chondrogenesis and the formation of long bones in endochondral ossification. 
Table 3. The skeletal developmental diseases that are used as models with iPSC formation.

\begin{tabular}{|c|c|c|c|}
\hline Disease & Factor/Mutation & Results & Ref \\
\hline $\begin{array}{c}\text { Achondroplasia }(\mathrm{ACH}) \\
\text { Hypochondroplasia }(\mathrm{HCH}) \text { and } \\
\text { Thanatophoric dysplasia (TD) }\end{array}$ & $\begin{array}{l}\text { ACH: FGFR3 c.1130G >A (p.G380R) } \\
\text { HCH: FGFR3 c.1620C >G (p.N540K) } \\
\text { TD1: FGFR3 c.742C>T (p.R248C) } \\
\text { TD2: FGFR3 c.746C>G (p.S249C) }\end{array}$ & $\begin{array}{l}\text { The FGFR inhibitor (NVP-BGJ398) has } \\
\text { corrected the failure of growth plate } \\
\text { formation during } \\
\text { chondrogenic differentiation. }\end{array}$ & Kimura et al., 2018 [169] \\
\hline $\begin{array}{l}\text { Achondroplasia }(\mathrm{ACH}) \text { and } \\
\text { Thanatophoric dysplasia (TD) }\end{array}$ & $\begin{array}{c}\text { ACH: FGFR3 c.1130G >A (p.G380R) } \\
\text { TD1: FGFR3 c.742C >T (p.R248C) }\end{array}$ & $\begin{array}{l}\text { The usage of statins during the } \\
\text { chondrogenic differentiation of } \\
\text { patient-derived iPSC has enabled the } \\
\text { formation of cartilage micromasses } \\
\text { and caused elongation of the bones in } \\
\text { transgenic mice }\end{array}$ & Yamashita et al., 2014 [163] \\
\hline Achondroplasia & ACH: FGFR3 c.1138G>A (p.G380R) & $\begin{array}{l}\text { Genetically modified cell line using } \\
\text { CRISPR/Cas9. Downregulation of } \\
\text { IHH in mutated cells leads to impaired } \\
\text { maturation of chondrogenic cells }\end{array}$ & Horie et al., 2017 [170] \\
\hline $\begin{array}{l}\text { Multiple epiphyseal dysplasia (MED) } \\
\text { and metaphyseal chondrodysplasia } \\
\text { type Schmid (MCDS) }\end{array}$ & $\begin{array}{c}\text { MED: MATN3 c.359C >T (p.T120M) } \\
\text { MATN3 c.659T >C (p.V220A) } \\
\text { MATN3 c.626G>C (p.R209P) } \\
\text { MCDS1: COL10A1 c.1841_1841delT } \\
\text { (p.L614Rfs*8)) } \\
\text { MCDS2: COL10A1 c.53G >A (p.G18E) } \\
\text { COL10A1 c.1798T>C (p.S600P) }\end{array}$ & $\begin{array}{l}\text { Intracellular retention of MATN3 and } \\
\text { COL10 in mutated cells leads to UPR } \\
\text { response, and its activation-dependent } \\
\text { on the mutations. The in vitro model } \\
\text { for drug testing and development } \\
\text { was formed }\end{array}$ & Pretemer et al., 2021 [171] \\
\hline $\begin{array}{c}\text { Type II collagenopathy: } \\
\text {-Achondrogenesis type II (ACGII) } \\
\text {-Hypochondrogenesis (HCG) } \\
\text {-Spondyloepiphyseal dysplasia (SPD) }\end{array}$ & $\begin{array}{l}\text { ACGII-1: T>C, exon 41-intron 40, exon } \\
\text { skipping } \\
\text { ACGII-2: COL2A1 c.3545G }>\text { A } \\
\text { (p.G1182A) } \\
\text { HCG-1: COL2A1 c.1348G>C (p.G450R) } \\
\text { SPD-1: COL2A1 c.4337dupG }\end{array}$ & $\begin{array}{l}\text { Intracellular accumulation of COL2 } \\
\text { decreased viability of obtained } \\
\text { iChondrocytes. It increased ER-stress } \\
\text { signalling due to a disturbed } \\
\text { regulation of protein folding. The } \\
\text { application of chemical chaperones } \\
\text { could partially improve the secretion } \\
\text { of COL2. }\end{array}$ & Okada et al., 2015 [172] \\
\hline $\begin{array}{l}\text { Familial Osteochondritis } \\
\text { Dissecans (FOCD) }\end{array}$ & ACAN c.6907G>A (p.V2303M) & $\begin{array}{l}\text { Increased accumulation of aggrecan in } \\
\text { cells caused ER stress. Abnormal } \\
\text { morphology of chondrocytes with a } \\
\text { reduced ability to endure mechanical } \\
\text { stress. The low amount of aggrecan } \\
\text { protein in the ECM. }\end{array}$ & Xu et al., 2016 [173] \\
\hline $\begin{array}{l}\text { Neonatal-onset multisystem } \\
\text { inflammatory disease (NOMID) }\end{array}$ & $\begin{array}{c}\text { Patient 1: } N \text { NLPP3 c.1709A }>\mathrm{G} \\
\text { (p.Y570C) } \\
\text { Patient 2: NLRP3 c.919G>A (p.G307S) }\end{array}$ & $\begin{array}{l}\text { The increased deposition of ECM and } \\
\text { irregular endochondral ossification } \\
\text { has been observed in mutant variants } \\
\text { of chondrogenically differentiated } \\
\text { iPSC. One of the potential causes was } \\
\text { the upregulation of SOX9 in the cells } \\
\text { mastered by the } \\
\text { cAMP/PKA/CREB pathway. }\end{array}$ & Yokoyama et al., 2015 [174] \\
\hline Metatropic dysplasia & TRPV4 c. $1812 \mathrm{C}>\mathrm{G}(\mathrm{p} . \mathrm{I} 604 \mathrm{M})$ & $\begin{array}{l}\text { Reduced expression of genes } \\
\text { responsible for cartilage growth } \\
\text { markers in chondrogenic micromasses } \\
\text { studied derived from TRPV4-iPSC. } \\
\text { The increased expression of COL1 and } \\
\text { irregular mineralisation patterns } \\
\text { during chondrogenesis indicate } \\
\text { abnormal differentiation } \\
\text { of chondrocytes. }\end{array}$ & Saitta et al., 2014 [175] \\
\hline $\begin{array}{l}\text { Fibrodysplasia ossificans progressiva } \\
\qquad \text { (FOP) }\end{array}$ & ACVR1 c.617G>A (p.R206H) & $\begin{array}{c}\text { Enhanced expression of } \\
\text { chondrogenesis related markers and } \\
\text { production of ECM observed } \\
\text { in FOP-iMSC. }\end{array}$ & Matsumoto et al., 2015 [176] \\
\hline Hand Osteoarthritis & $\begin{array}{c}\text { GDF5 SNP: rs143383 } \\
\text { SMAD3 SNP: rs12901499 } \\
\text { ALDH1A2 SNP: rs3204689 } \\
\text { IL1R1 rs2287047 }\end{array}$ & $\begin{array}{l}\text { Generated iPSC from patients with } \\
\text { risk alleles correlated with the hOA } \\
\text { exhibited decreased production of } \\
\text { COL2 and proteoglycans in } \\
\text { comparison with control }\end{array}$ & Castro-Viñuelas et al., 2020 [177] \\
\hline Early-onset finger OA (efOA) & Genetic background not tested & $\begin{array}{l}\text { The formation of vacuole-like } \\
\text { structures was observed in } \\
\text { chondrogenic masses formed in efOA } \\
\text { with unknown aetiology. Compared } \\
\text { to a healthy donor, the increased } \\
\text { expression of hypertrophic markers } \\
\text { and the secretion of cytokines and } \\
\text { MMPS related with OA in } \\
\text { chondrogenically differentiated } \\
\text { efOA-iPSC. }\end{array}$ & Rim et al., 2021 [178] \\
\hline
\end{tabular}


Table 3. Cont.

\begin{tabular}{ccc}
\hline Disease & Factor/Mutation & Results \\
\hline Osteoarthritis & Artificial induced OA by & The formation of mimicking \\
addition IL-1 $\beta$ & $\begin{array}{c}\text { osteochondral graft from iPSC cells } \\
\text { enables us to observe changes during } \\
\text { OA's induction and study the biology } \\
\text { of OA. This was shown by an } \\
\text { increased expression of catabolic } \\
\text { factors in constructed chips. }\end{array}$ \\
\hline
\end{tabular}

ACAN: aggrecan; ACGII: Achondrogenesis type II; ACH: Achondroplasia; ALDH1A2: Aldehyde dehydrogenase 1 family member A2; cAMP: 3', 5'-cyclic adenosine monophosphate; COL10A1: Alpha 1 type 10 collagen; COL2A1: Alpha 1 type II collagen; CREB: cAMP-response element-binding protein; CRISPR/Cas9: CRISPRassociated protein 9; ECM: extracellular matrix; efOA: early onset osteoarthritis; ER: endoplasmic reticulum; FGFR3:fibroblast growth factor receptor 3; FOCD: Familial Osteochondritis Dissecans; FOP: Fibrodysplasia ossificans progressiva; GDF5: Growth differentiation factor 5; HCG: Hypochondrogenesis; HCH: Hypochondroplasia; hOA: Hand Osteoarthritis; IHH: Indian hedgehog signaling molecule; IL-1 $\beta$ : Interleukin $1 \beta$; IL1R1: Interleukin 1 receptor, type I; iPSC: induced pluripotent stem cells; MATN3: Matrilin-3; MCDS: Metaphyseal chondrodysplasia type Schmid; MED: multiple epiphyseal dysplasia; MMP: metalloproteinases; NLRP3: NLR family pyrin domain containing 3; NOMID: Neonatal-onset multisystem inflammatory disease; PKA: cAMP-dependent protein kinase; SMAD3: SMAD family member 3; SNP: single-nucleotide polymorphism; SOX9: SRY-box transcription factor 9; SPD: Spondyloepiphyseal dysplasia; TD: Thanatophoric dysplasia; TRPV4: Transient receptor potential cation channel subfamily V member 4; UPR: unfolded protein response.

Chondrodysplasias are a group of severe diseases caused by disorganised development of the limbs and chondrogenesis itself. One of the most common mutations in the fibroblast growth factor 3 (FGFR3) gene, a negative regulator of bone development, is abnormally activated in these diseases. This leads to inappropriate skeletal formation via disorganisation of the endochondral ossification process [180]. The Kimura and Yamashita team created a model of achondroplasia, hypochondroplasia, and thanatophoric dysplasia based on their differentiation protocols $[112,163,169]$. They indicated that the use of statins might be helpful in the correction of bone growth in mice and repair the loss of the function of chondrocytes during their differentiation [163]. Similar observations were noted using the FGFR3 inhibitor, NVP-BGJ389, where xenotransplanted iPSC-derived chondrocytes from patients with FGFR3 mutations indicated a restoration of their function [169]. Interestingly, the model of this disease could also be formed artificially. Horie's team used the CRISPR/Cas9 method to generate a model of achondroplasia (p.G380R). In vitro differentiation of these cells revealed abnormalities via the downregulation of the Indian hedgehog signalling molecule $(I H H)$. This confirmed the correctly obtained model, since increased $\mathrm{IHH}$ is responsible for the maturation and pre-hypertrophy of chondrocytes [181].

Another group of disorders related to chondrogenesis that was studied using iPSC modelling is connected with the accumulation of proteins in the intracellular compartments of chondrocytes, leading to the activation of the unfolded protein response (UPR) [171,172,182]. Among them, we may distinguish multiple epiphyseal dysplasia (MED) and metaphyseal chondrodysplasia type Schmid (MCDS), which are related to the widening and irregularity of growth plates, an increased risk of developing early osteoarthritis of the knee and hip $[171,183,184]$. These diseases are related to the occurrence of mutations in type 10 collagen (COL10A1), a marker of hypertrophic chondrocytes, and matrilin-3 (MATN3), the protein responsible for terminal chondrogenic differentiation and homeostasis of the cartilage $[171,181,185,186]$. A recently published model of this disease by the Pretemer team revealed that the endoplasmic reticulum was significantly enlarged after the chondrogenic differentiation of COL10A1 and MATN3 mutants [171]. Histological staining also revealed the increased deposition of COL10 and matrilin-3 intracellularly in several mutants, a state partially reversed by using trimethylamine $\mathrm{N}$-oxide (TMAO), an agent acting as a chemical chaperone [171]. This compound was also studied in other diseases linked to the retention of type II collagen, a protein highly expressed in hyaline cartilage chondrocytes, which enables the stiffness and bearing of the mechanical loading of cartilage [172]. In general, those type II collagenopathies exhibit a lack of genotype-phenotype correlation and primarily present as abnormalities of ocular, otolaryngological, and skeletal systems with either a mild or severe bout of disease $[187,188]$. Interesting studies regarding that type of disease on the example of 
iPSC cell lines derived from patients with achondrogenesis type II (ACGII), hypochondrogenesis (HCG), and spondyloepiphyseal dysplasia (SPD) have shown an increased deposition of COL2 intracellularly and increased apoptosis of the affected cells. The use of TMAO, as in the above study, partially reduced the ER stress, enabled the secretion of type II collagen in the extracellular environment, and increased viability of the mutated cells [172]. Another rare disease related to the accumulation of mutated proteins in the intracellular compartments of chondrocytes with severe skeletal deformation outcomes is Familial Osteochondritis Dissecans (FOCD) [173]. The pathobiology of FOCD is linked with mutations in aggrecan (ACAN), a crucial component of articular cartilage proteoglycans, enabling the formation of dense ECM that protects chondrocytes and improves the binding of water molecules to maintain the biomechanical function of joints [189]. The analysis of chondrogenic pellets and nodules derived through the differentiation of iPSC from FOCD patients revealed a reduced presence of ACAN and ECM production compared to in healthy control. In addition, the increased deposits of ACAN were allocated in the ER, causing a severe stress response in those cells. The mass spectrometric analysis of the components of ECM revealed the increased expression of peptides, small leucine-rich proteoglycans (SLRPs), linked to OA and mineralisation during osteogenesis [173,190]. The chondrogenic differentiation of bone marrow MSC derived from the patients diagnosed with FOCD compared to iPSC-derived cells also revealed similarities that confirmed their usefulness as a model of that disease and potential platform for studying potential therapeutic approaches.

The Yokoyama team developed another successfully developed disease model. They created a model of neonatal-onset multisystem inflammatory disease (NOMID), a rare disease caused by a mutation in the NLR family pyrin domain-containing 3 (NLRP3) gene encoding protein cryopyrin [174]. That mutation caused a pathological abnormal systemic inflammation response via the increased formation of multiprotein complexes called inflammasomes. Their activation leads to the increased release of IL- $1 \beta$, a widely known cytokine responsible for increased catabolic reactions in cartilage [191,192]. One of the manifestations of the disease is related to the enlarged epiphyseal and disorganised structure of isogenic groups of cartilage [193]. The chondrogenic in vitro differentiation of mutant iPSC cells resulted in large cartilaginous masses with increased ECM/GAG production. The NOMID-derived chondrocytes also matured in vivo and exhibited a disorganised endochondral ossification process and increased mass. Their study explained that the enlarged cartilaginous masses were related to the co-upregulation of SOX9, the master transcription factor of chondrocytes, via the cAMP/PKA/CREB signalling pathway in the chondrogenically differentiated, mutated iPSC clones [174].

Among models of skeletal developmental disorders, metatropic dysplasia was established by the Saitta team using cells from a patient carrying a lethal mutation $(\mathrm{C} 1812>\mathrm{G})$ of the transient receptor potential cation channel, subfamily V, member 4 (TRPV4) [175]. This defect is responsible for the dysregulation of $\mathrm{Ca}^{2+}$ homeostasis of chondrogenic or neural cells [194]. This type of disease correlates with metaphyseal enlargement, dwarfism, cervical instability, and severe kyphoscoliosis [195,196]. The in vitro chondrogenic differentiation of mutated iPSC clones revealed the reduced production of COL2 with a parallel increased production of COL1 in comparison with healthy iPSC. The gene expression analysis also showed that COL10A1 and RUNX2, markers characteristic of the late stages of chondrogenesis, were downregulated compared to the control. This explains why the hypertrophic zone of articular cartilage was reduced and chondrogenic maturation was weakened [175].

The Matsumoto team made another interesting observation. They established the iPSC model from a patient with fibrodysplasia ossificans progressiva (FOP) [176]. This rare genetic disease is characterised by replacing muscle and connective tissue with bone due to severe damage, invasive procedures, or infectious diseases [197]. One characteristic trait of the disease is the malformation of the great toes. The mutations in the activin receptor type I (ACVR1) are responsible for the occurrence of the disease, which is related to its binding ability of BMP proteins known for their osteoinductive properties [198,199]. In 
this model, the differentiated cells exhibited a higher deposition of ECM and an expression of chondrogenic markers (SOX9, COL2A1, and ACAN) than with the control iPSC cells (genetically corrected FOP-iPSC). The comparative gene expression profile of the mutated and corrected iPSC cells enabled researchers to identify MMP1 and PAI1 as the proteins responsible for enhanced chondrogenesis and its partial activation via the SMAD signalling pathway. The chemical inhibitors (GM6001 and tiplaxitin) partially reduced the production of GAG and the area of chondrogenic micromasses cultured 2D [176].

In addition to several types of skeletal dysplasia, a number of OA models have also been created, such as hand OA, early-onset finger OA, and chemically induced OA (stimulation of a formed osteochondral plug in a dual-flow bioreactor with IL-1 $\beta$ ) [177-179]. The introduction mentioned that $\mathrm{OA}$ is a complex disease with several environmental and genetic background factors [12]. Both the Rims and Castro-Viñuelas teams' studies yielded similar data, showing the less chondrogenic potential of iPSC from OA patients than in healthy donors. It was assessed by the reduced expression of hyaline cartilage markers deposition of the ECM with a parallel increased expression of hypertrophic markers related to the late stages of chondrogenesis $[177,178]$. Lin et al. carried out an interesting study, in which they created a construct that consisted of mesenchymal progenitor cells derived from iPSC cells suspended in methacrylate gelatin, which was used to create an osteochondral plug in the dual-flow bioreactor [179]. The bottom of the construct was exposed to an osteogenic cell culture medium, and the top was rinsed in a chondrogenic medium. This allowed the creation of the first model imitating a full-thickness osteochondral plug for testing drugs. They confirmed the utility of that model by inducing OA using IL- $1 \beta$, which indicated a reduced expression of chondrogenic markers (ACAN and COL2) and increased cartilage-degrading proteins (MMPs and ADMTS). The use of Celecoxib, a potent diseasemodifying osteoarthritis drug, showed its chondroprotective properties by reducing the catabolic and proinflammatory induced response [179].

It is worth mentioning that the recent data indicated the derivation of new iPSC cell lines from patients with cleidocranial dysplasia (deletion of exon 3 of RUNX2) and acromesomelic dysplasia (PRKG2, frameshift insertion). Neither has the effect of those disorders yet to be elucidated on in vitro or in vivo chondrogenesis [200,201].

\section{Conclusions}

The recently obtained breadth of knowledge concerning the chondrogenesis process and the establishment of several well-defined differentiation protocols with good in vivo outcomes could yield a strong base for forming clinical trials in that area soon. For now, these protocols enable the discovery of the bias of skeletal development pathologies and establish practical disease models for the screening of drugs and studies of mechanisms explaining the biology of those diseases without the necessity of an extensive collection of materials from patients.

Author Contributions: Conceptualisation, M.S.L. and M.A.R.; writing—original draft preparation M.S.L., M.A.R., M.R., I.J., W.M.S. and T.T.; writing-review and editing, M.S.L., M.A.R., M.R., I.J., W.M.S. and T.T.; visualisation, M.S.L.; supervision T.T. and W.M.S.; and funding acquisition, T.T. All authors have read and agreed to the published version of the manuscript.

Funding: This research was funded by the National Science Centre based on decision no. UMO2019/33/B/NZ5/01989.

Institutional Review Board Statement: Not applicable.

Informed Consent Statement: Not applicable.

Data Availability Statement: Not applicable.

Conflicts of Interest: The authors declare no conflict of interest. 


\section{References}

1. Barbero, A.; Grogan, S.; Schäfer, D.; Heberer, M.; Mainil-Varlet, P.; Martin, I. Age related changes in human articular chondrocyte yield, proliferation and post-expansion chondrogenic capacity. Osteoarthr. Cartil. 2004, 12, 476-484. [CrossRef] [PubMed]

2. Jämsen, E.; Nevalainen, P.; Eskelinen, A.; Huotari, K.; Kalliovalkama, J.; Moilanen, T. Obesity, Diabetes, and Preoperative Hyperglycemia as Predictors of Periprosthetic Joint Infection. J. Bone Jt. Surg. 2012, 94, e101. [CrossRef] [PubMed]

3. Manek, N.J.; Hart, D.; Spector, T.D.; MacGregor, A.J. The association of body mass index and osteoarthritis of the knee joint: An examination of genetic and environmental influences. Arthritis Care Res. 2003, 48, 1024-1029. [CrossRef] [PubMed]

4. Harris, J.D.; Brophy, R.H.; Siston, R.A.; Flanigan, D.C. Treatment of Chondral Defects in the Athlete's Knee. Arthrosc. J. Arthrosc. Relat. Surg. 2010, 26, 841-852. [CrossRef] [PubMed]

5. Garstang, S.V.; Stitik, T.P. Osteoarthritis. Am. J. Phys. Med. Rehabil. 2006, 85, S2-S11. [CrossRef]

6. Li, Y.P.; Wei, X.C.; Zhou, J.M.; Wei, L. The Age-Related Changes in Cartilage and Osteoarthritis. BioMed Res. Int. $2013,2013,1-12$. [CrossRef] [PubMed]

7. Pulsatelli, L.; Addimanda, O.; Brusi, V.; Pavloska, B.; Meliconi, R. New findings in osteoarthritis pathogenesis: Therapeutic implications. Ther. Adv. Chronic Dis. 2012, 4, 23-43. [CrossRef]

8. Koelling, S.; Kruegel, J.; Irmer, M.; Path, J.R.; Sadowski, B.; Miro, X.; Miosge, N. Migratory Chondrogenic Progenitor Cells from Repair Tissue during the Later Stages of Human Osteoarthritis. Cell Stem Cell 2009, 4, 324-335. [CrossRef]

9. Bertrand, J.; Cromme, C.; Umlauf, D.; Frank, S.; Pap, T. Molecular mechanisms of cartilage remodelling in osteoarthritis. Int. J. Biochem. Cell Biol. 2010, 42, 1594-1601. [CrossRef]

10. Wang, Y.; Wluka, A.; Jones, G.; Ding, C.; Cicuttini, F.M. Use magnetic resonance imaging to assess articular cartilage. Ther. Adv. Musculoskelet. Dis. 2011, 4, 77-97. [CrossRef]

11. Jungmann, P.M.; Baum, T.; Bauer, J.S.; Karampinos, D.; Erdle, B.; Link, T.M.; Li, X.; Trattnig, S.; Rummeny, E.J.; Woertler, K.; et al. Cartilage Repair Surgery: Outcome Evaluation by Using Noninvasive Cartilage Biomarkers Based on Quantitative MRI Techniques? BioMed Res. Int. 2014, 2014, 1-17. [CrossRef] [PubMed]

12. Wieland, H.A.; Michaelis, M.; Kirschbaum, B.J.; Rudolphi, K.A. Osteoarthritis-An untreatable disease? Nat. Rev. Drug Discov. 2005, 4, 331-344. [CrossRef] [PubMed]

13. Oldershaw, R.A. Cell sources for the regeneration of articular cartilage: The past, the horizon and the future. Int. J. Exp. Pathol. 2012, 93, 389-400. [CrossRef] [PubMed]

14. Yang, W.; Lee, S.; Jo, Y.; Lee, K.; Nemeno, J.; Nam, B.; Kim, B.; Jang, I.; Kim, H.; Takebe, T.; et al. Effects of Natural Cartilaginous Extracellular Matrix on Chondrogenic Potential for Cartilage Cell Transplantation. Transplant. Proc. 2014, 46, 1247-1250. [CrossRef]

15. Vynios, D.H. Metabolism of Cartilage Proteoglycans in Health and Disease. BioMed Res. Int. 2014, 2014, 1-9. [CrossRef]

16. Vinatier, C.; Mrugala, D.; Jorgensen, C.; Guicheux, J.; Noël, D. Cartilage engineering: A crucial combination of cells, biomaterials and biofactors. Trends Biotechnol. 2009, 27, 307-314. [CrossRef]

17. Gomoll, A.H.; Minas, T. The quality of healing: Articular cartilage. Wound Repair Regen. 2014, 22, 30-38. [CrossRef]

18. Steele, J.; McCullen, S.; Callanan, A.; Autefage, H.; Accardi, M.; Dini, D.; Stevens, M. Combinatorial scaffold morphologies for zonal articular cartilage engineering. Acta Biomater. 2014, 10, 2065-2075. [CrossRef]

19. Klein, T.; Malda, J.; Sah, R.L.; Hutmacher, D.W. Tissue Engineering of Articular Cartilage with Biomimetic Zones. Tissue Eng. Part B Rev. 2009, 15, 143-157. [CrossRef]

20. Perez, R.; Won, J.-E.; Knowles, J.C.; Kim, H.-W. Naturally and synthetic smart composite biomaterials for tissue regeneration. Adv. Drug Deliv. Rev. 2013, 65, 471-496. [CrossRef]

21. Gomes, S.; Leonor, I.B.; Mano, J.F.; Reis, R.L.; Kaplan, D.L. Natural and genetically engineered proteins for tissue engineering Prog. Polym. Sci. 2012, 37, 1-17. [CrossRef] [PubMed]

22. Demoor, M.; Ollitrault, D.; Gomez-Leduc, T.; Bouyoucef, M.; Hervieu, M.; Fabre, H.; Lafont, J.; Denoix, J.-M.; Audigié, F.; Mallein-Gerin, F.; et al. Cartilage tissue engineering: Molecular control of chondrocyte differentiation for proper cartilage matrix reconstruction. Biochim. et Biophys. Acta (BBA) - Gen. Subj. 2014, 1840, 2414-2440. [CrossRef] [PubMed]

23. Medvedeva, E.V.; Grebenik, E.A.; Gornostaeva, S.N.; Telpuhov, V.I.; Lychagin, A.V.; Timashev, P.S.; Chagin, A.S. Repair of Damaged Articular Cartilage: Current Approaches and Future Directions. Int. J. Mol. Sci. 2018, 19, 2366. [CrossRef] [PubMed]

24. Nehrer, S.; Brix, M. Long-Term Outcomes of Chondrocyte-Based Cartilage Repair. Oper. Tech. Orthop. 2014, 24, 48-53. [CrossRef]

25. De Windt, T.S.; Vonk, L.A.; Brittberg, M.; Saris, D.B. Treatment and Prevention of (Early) Osteoarthritis Using Articular Cartilage Repair-Fact or Fiction? A Systematic Review. Cartilage 2013, 4, 5S-12S. [CrossRef] [PubMed]

26. Schmal, H.; Pestka, J.M.; Salzmann, G.; Strohm, P.C.; Südkamp, N.P.; Niemeyer, P. Autologous chondrocyte implantation in children and adolescents. Knee Surg. Sports Traumatol. Arthrosc. 2012, 21, 671-677. [CrossRef]

27. Minas, T.; Gomoll, A.H.; Rosenberger, R.; Royce, R.O.; Bryant, T. Increased Failure Rate of Autologous Chondrocyte Implantation after Previous Treatment with Marrow Stimulation Techniques. Am. J. Sports Med. 2009, 37, 902-908. [CrossRef]

28. Siclari, A.; Mascaro, G.; Gentili, C.; Kaps, C.; Cancedda, R.; Boux, E. Cartilage repair in the knee with subchondral drilling augmented with a platelet-rich plasma-immersed polymer-based implant. Knee Surg. Sports Traumatol. Arthrosc. 2014, 22, 1225-1234. [CrossRef]

29. Kreuz, P.; Steinwachs, M.; Erggelet, C.; Krause, S.; Konrad, G.; Uhl, M.; Südkamp, N. Results after microfracture of full-thickness chondral defects in different compartments in the knee. Osteoarthr. Cartil. 2006, 14, 1119-1125. [CrossRef] 
30. Trattnig, S.; Millington, S.A.; Szomolanyi, P.; Marlovits, S. MR imaging of osteochondral grafts and autologous chondrocyte implantation. Eur. Radiol. 2006, 17, 103-118. [CrossRef]

31. Cole, B.J.; Pascual-Garrido, C.; Grumet, R.C. Surgical management of articular cartilage defects in the knee. J. Bone Jt. Surg. 2009, 91, 1778-1790.

32. Hindle, P.; Hendry, J.L.; Keating, J.F.; Biant, L.C. Autologous osteochondral mosaicplasty or TruFit ${ }^{\mathrm{TM}}$ plugs for cartilage repair. Knee Surg. Sports Traumatol. Arthrosc. 2013, 22, 1235-1240. [CrossRef] [PubMed]

33. Heir, S.; Årøen, A.; Løken, S.; Holme, I.; Engebretsen, L.; Reinholt, F.P. Cartilage repair in the rabbit knee: Mosaic plasty resulted in higher degree of tissue filling but affected subchondral bone more than microfracture technique. Knee Surg. Sports Traumatol. Arthrosc. 2011, 20, 197-209. [CrossRef] [PubMed]

34. Pareek, A.; Reardon, P.J.; Macalena, J.A.; Levy, B.A.; Stuart, M.J.; Williams, R.J.; Krych, A.J. Osteochondral Autograft Transfer Versus Microfracture in the Knee: A Meta-analysis of Prospective Comparative Studies at Midterm. Arthrosc. J. Arthrosc. Relat. Surg. 2016, 32, 2118-2130. [CrossRef] [PubMed]

35. Li, X.A.; Iyer, S.; Cross, M.B.; Figgie, M.P. Total joint replacement in adolescents. Curr. Opin. Pediatr. 2012, 24, 57-63. [CrossRef] [PubMed]

36. Ando, W.; Yasui, H.; Yamamoto, K.; Oinuma, K.; Tokunaga, H.; Inaba, Y.; Kobayashi, N.; Aihara, M.; Nakanishi, R.; Ohzono, K. A comparison of the effect of large and small metal-on-metal bearings in total hip arthroplasty on metal ion levels and the incidence of pseudotumour. Bone Jt. J. 2018, 100-B, 1018-1024. [CrossRef] [PubMed]

37. Reito, A.; Parkkinen, J.; Puolakka, T.; Pajamäki, J.; Eskelinen, A. Diagnostic utility of joint fluid metal ion measurement for histopathological findings in metal-on-metal hip replacements. BMC Musculoskelet. Disord. 2015, 16, 1-12. [CrossRef]

38. Gomoll, A.H.; Filardo, G.; DE Girolamo, L.; Esprequeira-Mendes, J.; Marcacci, M.; Rodkey, W.G.; Steadman, R.J.; Zaffagnini, S.; Kon, E. Surgical treatment for early osteoarthritis. Part I: Cartilage repair procedures. Knee Surg. Sports Traumatol. Arthrosc. 2011, 20, 450-466. [CrossRef]

39. Wang, C.-C.; Yang, K.-C.; Lin, K.-H.; Liu, H.-C.; Lin, F.-H. A highly organized three-dimensional alginate scaffold for cartilage tissue engineering prepared by microfluidic technology. Biomaterials 2011, 32, 7118-7126. [CrossRef]

40. Toh, W.S.; Guo, X.-M.; Choo, A.B.; Lu, K.; Lee, E.H.; Cao, T. Differentiation and enrichment of expandable chondrogenic cells from human embryonic stem cells in vitro. J. Cell. Mol. Med. 2009, 13, 3570-3590. [CrossRef]

41. Heywood, H.K.; Nalesso, G.; Lee, D.A.; Dell'Accio, F. Culture Expansion in Low-Glucose Conditions Preserves Chondrocyte Differentiation and Enhances Their Subsequent Capacity to Form Cartilage Tissue in Three-Dimensional Culture. BioResearch Open Access 2014, 3, 9-18. [CrossRef] [PubMed]

42. Chen, J.-L.; Duan, L.; Zhu, W.; Xiong, J.; Wang, D. Extracellular matrix production in vitro in cartilage tissue engineering. J. Transl. Med. 2014, 12, 88. [CrossRef] [PubMed]

43. Saris, D.B.F.; Vanlauwe, J.; Victor, J.; Haspl, M.; Bohnsack, M.; Fortems, Y.; Vandekerckhove, B.; Almqvist, K.F.; Claes, T.; Handelberg, F.; et al. Characterized Chondrocyte Implantation Results in Better Structural Repair when Treating Symptomatic Cartilage Defects of the Knee in a Randomized Controlled Trial versus Microfracture. Am. J. Sports Med. 2008, 36, 235-246. [CrossRef] [PubMed]

44. Kamarul, T.; Selvaratnam, L.; Masjuddin, T.; Ab-Rahim, S.; Ng, C.; Chan, K.; Ahmad, T.S. Autologous Chondrocyte Transplantation in the Repair of Full-Thickness Focal Cartilage Damage in Rabbits. J. Orthop. Surg. 2008, 16, 230-236. [CrossRef] [PubMed]

45. Ozbey, O.; Sahin, Z.; Acar, N.; Ozcelik, F.T.; Ozenci, A.M.; Koksoy, S.; Ustunel, I. Characterization of colony-forming cells in adult human articular cartilage. Acta Histochem. 2014, 116, 763-770. [CrossRef]

46. Lahner, M.; Duif, C.; Ficklscherer, A.; Kaps, C.; Kalwa, L.; Seidl, T. Arthroscopic Fixation of Cell Free Polymer-Based Cartilage Implants with a Bioinspired Polymer Surface on the Hip Joint: A Cadaveric Pilot Study. BioMed Res. Int. 2014, $2014,1-6$. [CrossRef]

47. Schrock, J.B.; Kraeutler, M.J.; Houck, D.A.; McQueen, M.B.; Mccarty, E.C. A Cost-Effectiveness Analysis of Surgical Treatment Modalities for Chondral Lesions of the Knee: Microfracture, Osteochondral Autograft Transplantation, and Autologous Chondrocyte Implantation. Orthop. J. Sports Med. 2017, 5, 232596711770463. [CrossRef]

48. Inderhaug, E.; Solheim, E. Osteochondral Autograft Transplant (Mosaicplasty) for Knee Articular Cartilage Defects. JBJS Essent. Surg. Tech. 2019, 9, e34. [CrossRef]

49. Gudas, R.; Gudaitè, A.; Pocius, A.; Gudienè, A.; Čekanauskas, E.; Monastyreckienè, E.; Basevičius, A. Ten-Year Follow-up of a Prospective, Randomized Clinical Study of Mosaic Osteochondral Autologous Transplantation Versus Microfracture for the Treatment of Osteochondral Defects in the Knee Joint of Athletes. Am. J. Sports Med. 2012, 40, 2499-2508. [CrossRef]

50. Patil, S.; Tapasvi, S.R. Osteochondral autografts. Curr. Rev. Musculoskelet. Med. 2015, 8, 423-428. [CrossRef]

51. Wu, X.-D.; Xu, W.; Tian, M.; Cheng, Q.; Huang, W. Cup-on-cup technique to manage severe protrusio acetabular defects. Ann. R. Coll. Surg. Engl. 2018, 100, e181-e184. [CrossRef] [PubMed]

52. Takahashi, K.; Yamanaka, S. Induction of Pluripotent Stem Cells from Mouse Embryonic and Adult Fibroblast Cultures by Defined Factors. Cell 2006, 126, 663-676. [CrossRef] [PubMed]

53. Takahashi, K.; Tanabe, K.; Ohnuki, M.; Narita, M.; Ichisaka, T.; Tomoda, K.; Yamanaka, S. Induction of Pluripotent Stem Cells from Adult Human Fibroblasts by Defined Factors. Cell 2007, 131, 861-872. [CrossRef] [PubMed]

54. Mitalipov, S.; Wolf, D. Totipotency, Pluripotency and Nuclear Reprogramming. Eng. Stem Cells 2009, 114, 185-199. 
55. Mikkelsen, T.S.; Hanna, J.; Zhang, X.; Ku, M.; Wernig, M.; Schorderet, P.; Bernstein, B.E.; Jaenisch, R.; Lander, E.S.; Meissner, A. Dissecting direct reprogramming through integrative genomic analysis. Nature 2008, 454, 49-55. [CrossRef]

56. Stadtfeld, M.; Maherali, N.; Breault, D.T.; Hochedlinger, K. Defining Molecular Cornerstones during Fibroblast to iPS Cell Reprogramming in Mouse. Cell Stem Cell 2008, 2, 230-240. [CrossRef]

57. Brambrink, T.; Foreman, R.; Welstead, G.G.; Lengner, C.; Wernig, M.; Suh, H.; Jaenisch, R. Sequential Expression of Pluripotency Markers during Direct Reprogramming of Mouse Somatic Cells. Cell Stem Cell 2008, 2, 151-159. [CrossRef]

58. Omole, A.E.; Fakoya, A.O.J. Ten years of progress and promise of induced pluripotent stem cells: Historical origins, characteristics, mechanisms, limitations, and potential applications. PeerJ 2018, 6, e4370. [CrossRef]

59. Stadtfeld, M.; Nagaya, M.; Utikal, J.; Weir, G.; Hochedlinger, K. Induced Pluripotent Stem Cells Generated Without Viral Integration. Science 2008, 322, 945-949. [CrossRef]

60. Turinetto, V.; Orlando, L.; Giachino, C. Induced Pluripotent Stem Cells: Advances in the Quest for Genetic Stability during Reprogramming Process. Int. J. Mol. Sci. 2017, 18, 1952. [CrossRef]

61. Lyssiotis, C.; Foreman, R.K.; Staerk, J.; Garcia, M.; Mathur, D.; Markoulaki, S.; Hanna, J.H.; Lairson, L.; Charette, B.D.; Bouchez, L.C.; et al. Reprogramming of murine fibroblasts to induced pluripotent stem cells with chemical complementation of Klf4. Proc. Natl. Acad. Sci. USA 2009, 106, 8912-8917. [CrossRef] [PubMed]

62. Kim, J.B.; Greber, B.; Araúzo-Bravo, M.J.; Meyer, J.; Park, K.I.; Zaehres, H.; Schöler, H. Direct reprogramming of human neural stem cells by OCT4. Nature 2009, 461, 649-653. [CrossRef]

63. Krizhanovsky, V.; Lowe, S.W. The promises and perils of p53. Nature 2009, 460, 1085-1086. [CrossRef] [PubMed]

64. Stelcer, E.; Kulcenty, K.; Rucinski, M.; Jopek, K.; Richter, M.; Trzeciak, T.; Suchorska, W.M. Forced differentiation in vitro leads to stress-induced activation of DNA damage response in hiPSC-derived chondrocyte-like cells. PLoS ONE 2018, 13, e0198079. [CrossRef] [PubMed]

65. Oleksiewicz, U.; Gładych, M.; Raman, A.T.; Heyn, H.; Mereu, E.; Chlebanowska, P.; Andrzejewska, A.; Sozańska, B.; Samant, N.; Fak, K.; et al. TRIM28 and Interacting KRAB-ZNFs Control Self-Renewal of Human Pluripotent Stem Cells through Epigenetic Repression of Pro-differentiation Genes. Stem Cell Rep. 2017, 9, 2065-2080. [CrossRef] [PubMed]

66. Luo, M.; Ling, T.; Xie, W.; Sun, H.; Zhou, Y.; Zhu, Q.; Shen, M.; Zong, L.; Lyu, G.; Zhao, Y.; et al. NuRD Blocks Reprogramming of Mouse Somatic Cells into Pluripotent Stem Cells. Stem Cells 2013, 31, 1278-1286. [CrossRef]

67. Liu, X.; Li, W.; Fu, X.; Xu, Y. The Immunogenicity and Immune Tolerance of Pluripotent Stem Cell Derivatives. Front. Immunol. 2017, 8, 645. [CrossRef]

68. Eguizabal, C.; Aran, B.; Lopes, S.M.C.D.S.; Geens, M.; Heindryckx, B.; Panula, S.; Popovic, M.; Vassena, R.; Veiga, A. Two decades of embryonic stem cells: A historical overview. Hum. Reprod. Open 2019, 2019, hoy024. [CrossRef]

69. Garreta, E.; Sanchez, S.; Lajara, J.; Montserrat, N.; Belmonte, J.C.I. Roadblocks in the Path of iPSC to the Clinic. Curr. Transplant. Rep. 2018, 5, 14-18. [CrossRef]

70. Cao, J.; Li, X.; Lu, X.; Zhang, C.; Yu, H.; Zhao, T. Cells derived from iPSC can be immunogenic - Yes or No? Protein Cell 2014, 5, 1-3. [CrossRef]

71. Kaneko, S.; Yamanaka, S. To Be Immunogenic, or Not to Be: That's the iPSC Question. Cell Stem Cell 2013, 12, 385-386. [CrossRef] [PubMed]

72. Zhao, T.; Zhang, Z.-N.; Rong, Z.; Xu, Y. Immunogenicity of induced pluripotent stem cells. Nature 2011, 474, 212-215. [CrossRef] [PubMed]

73. Li, C.; Chen, S.; Zhou, Y.; Zhao, Y.; Liu, P.; Cai, J. Application of induced pluripotent stem cell transplants: Autologous or allogeneic? Life Sci. 2018, 212, 145-149. [CrossRef] [PubMed]

74. Deuse, T.; Hu, X.; Gravina, A.; Wang, D.; Tediashvili, G.; De, C.; Thayer, W.O.; Wahl, A.; Garcia, J.V.; Reichenspurner, H.; et al Hypoimmunogenic derivatives of induced pluripotent stem cells evade immune rejection in fully immunocompetent allogeneic recipients. Nat. Biotechnol. 2019, 37, 252-258. [CrossRef] [PubMed]

75. Jacquet, L.; Stephenson, E.; Collins, R.; Patel, H.; Trussler, J.; Al-Bedaery, R.; Renwick, P.; Ogilvie, C.; Vaughan, R.; Ilic, D. Strategy for the creation of clinical grade hESC line banks that HLA-match a target population. EMBO Mol. Med. 2012, 5, 10-17. [CrossRef] [PubMed]

76. Taylor, C.J.; Peacock, S.; Chaudhry, A.N.; Bradley, J.A.; Bolton, E. Generating an iPSC Bank for HLA-Matched Tissue Transplantation Based on Known Donor and Recipient HLA Types. Cell Stem Cell 2012, 11, 147-152. [CrossRef]

77. De Almeida, P.E.; Ransohoff, J.D.; Nahid, A.; Wu, J.C. Immunogenicity of Pluripotent Stem Cells and Their Derivatives. Circ. Res. 2013, 112, 549-561. [CrossRef]

78. Caplan, A.I. Mesenchymal Stem Cells: Time to Change the Name! STEM CELLS Transl. Med. 2017, 6, 1445-1451. [CrossRef]

79. Viswanathan, S.; Shi, Y.; Galipeau, J.; Krampera, M.; Leblanc, K.; Martin, I.; Nolta, J.; Phinney, D.G.; Sensebe, L. Mesenchymal stem versus stromal cells: International Society for Cell \& Gene Therapy (ISCT®) Mesenchymal Stromal Cell committee position statement on nomenclature. Cytotherapy 2019, 21, 1019-1024. [CrossRef]

80. Beane, O.S.; Darling, E.M. Isolation, Characterization, and Differentiation of Stem Cells for Cartilage Regeneration. Ann. Biomed. Eng. 2012, 40, 2079-2097. [CrossRef]

81. Tsvetkova, A.V.; Vakhrushev, I.V.; Basok, Y.B.; Grigor'Ev, A.M.; Kirsanova, L.A.; Lupatov, A.Y.; Sevastianov, V.I.; Yarygin, K.N. Chondrogeneic Potential of MSC from Different Sources in Spheroid Culture. Bull. Exp. Biol. Med. 2021, 170, 528-536. [CrossRef] [PubMed] 
82. Wu, X.; Jiang, J.; Gu, Z.; Zhang, J.; Chen, Y.; Liu, X. Mesenchymal stromal cell therapies: Immunomodulatory properties and clinical progress. Stem Cell Res. Ther. 2020, 11, 1-16. [CrossRef] [PubMed]

83. Grégoire, C.; Ritacco, C.; Hannon, M.; Seidel, L.; Delens, L.; Belle, L.; Dubois, S.; Vériter, S.; Lechanteur, C.; Briquet, A.; et al Comparison of Mesenchymal Stromal Cells From Different Origins for the Treatment of Graft-vs.-Host-Disease in a Humanized Mouse Model. Front. Immunol. 2019, 10. [CrossRef] [PubMed]

84. Petrenko, Y.; Vackova, I.; Kekulova, K.; Chudickova, M.; Koci, Z.; Turnovcova, K.; Skalnikova, H.K.; Vodicka, P.; Kubinova, S. A Comparative Analysis of Multipotent Mesenchymal Stromal Cells derived from Different Sources, with a Focus on Neuroregenerative Potential. Sci. Rep. 2020, 10, 1-15. [CrossRef] [PubMed]

85. Mohamed-Ahmed, S.; Fristad, I.; Lie, S.A.; Suliman, S.; Mustafa, K.; Vindenes, H.; Idris, S.B. Adipose-derived and bone marrow mesenchymal stem cells: A donor-matched comparison. Stem Cell Res. Ther. 2018, 9, 1-15. [CrossRef] [PubMed]

86. Pievani, A.; Scagliotti, V.; Russo, F.M.; Azario, I.; Rambaldi, B.; Sacchetti, B.; Marzorati, S.; Erba, E.; Giudici, G.; Riminucci, M.; et al Comparative analysis of multilineage properties of mesenchymal stromal cells derived from fetal sources shows an advantage of mesenchymal stromal cells isolated from cord blood in chondrogenic differentiation potential. Cytotherapy 2014, 16, 893-905. [CrossRef] [PubMed]

87. Na Yang, H.; Park, J.S.; Woo, D.G.; Jeon, S.Y.; Do, H.-J.; Lim, H.-Y.; Kim, S.W.; Kim, J.-H.; Park, K.-H. Chondrogenesis of mesenchymal stem cells and dedifferentiated chondrocytes by transfection with SOX Trio genes. Biomaterials 2011, 32, 7695-7704. [CrossRef]

88. Brown, P.T.; Squire, M.W.; Li, W.-J. Characterization and evaluation of mesenchymal stem cells derived from human embryonic stem cells and bone marrow. Cell Tissue Res. 2014, 358, 149-164. [CrossRef]

89. Abujarour, R.; Valamehr, B.; Robinson, M.; Rezner, B.; Vranceanu, F.; Flynn, P. Optimized Surface Markers for the Prospective Isolation of High-Quality hiPSCs using Flow Cytometry Selection. Sci. Rep. 2013, 3, srep01179. [CrossRef]

90. Priester, C.; Macdonald, A.; Dhar, M.; Bow, A. Examining the Characteristics and Applications of Mesenchymal, Induced Pluripotent, and Embryonic Stem Cells for Tissue Engineering Approaches across the Germ Layers. Pharmaceuticals 2020, 13, 344 [CrossRef]

91. Yilmazer, A.; De Lázaro, I.; Bussy, C.; Kostarelos, K. In vivo reprogramming of adult somatic cells to pluripotency by overexpression of Yamanaka factors. J. Vis. Exp. 2013, e50837, e50837. [CrossRef] [PubMed]

92. Gutierrez-Aranda, I.; Ramos-Mejia, V.; Bueno, C.; Munoz-Lopez, M.; Real, P.J.; Mácia, A.; Sanchez, L.; Ligero, G.; Garcia-Parez, J.L.; Menendez, P. Human Induced Pluripotent Stem Cells Develop Teratoma More Efficiently and Faster Than Human Embryonic Stem Cells Regardless the Site of Injection. Stem Cells 2010, 28, 1568-1570. [CrossRef] [PubMed]

93. Ben-David, U.; Gan, Q.-F.; Golan-Lev, T.; Arora, P.; Yanuka, O.; Oren, Y.S.; Leikin-Frenkel, A.; Graf, M.; Garippa, R.; Boehringer, M.; et al. Selective Elimination of Human Pluripotent Stem Cells by an Oleate Synthesis Inhibitor Discovered in a High-Throughput Screen. Cell Stem Cell 2013, 12, 167-179. [CrossRef] [PubMed]

94. Miyazaki, T.; Hanamatsu, H.; Xu, L.; Onodera, T.; Furukawa, J.-I.; Homan, K.; Baba, R.; Kawasaki, T.; Iwasaki, N. Evaluation of Residual Human-Induced Pluripotent Stem Cells in Human Chondrocytes by Cell Type-Specific Glycosphingolipid Glycome Analysis Based on the Aminolysis-SALSA Technique. Int. J. Mol. Sci. 2019, 21, 231. [CrossRef]

95. Guan, X.; Xu, W.; Zhang, H.; Wang, Q.; Yu, J.; Zhang, R.; Chen, Y.; Xia, Y.; Wang, J.; Wang, D. Transplantation of human induced pluripotent stem cell-derived cardiomyocytes improves myocardial function and reverses ventricular remodeling in infarcted rat hearts. Stem Cell Res. Ther. 2020, 11, 1-11. [CrossRef]

96. Lotz, M.K. New developments in osteoarthritis: Posttraumatic osteoarthritis: Pathogenesis and pharmacological treatment options. Arthritis Res. Ther. 2010, 12, 1-9. [CrossRef]

97. Ng, F.; Boucher, S.; Koh, S.; Sastry, K.S.R.; Chase, L.; Lakshmipathy, U.; Choong, C.; Yang, Z.; Vemuri, M.C.; Rao, M.S.; et al PDGF, TGF- $\beta$, and FGF signaling is important for differentiation and growth of mesenchymal stem cells (MSCs): Transcriptional profiling can identify markers and signaling pathways important in differentiation of MSCs into adipogenic, chondrogenic, and osteogenic lineages. Blood 2008, 112, 295-307. [CrossRef]

98. Hanada, K.; Solchaga, L.A.; Caplan, A.I.; Hering, T.M.; Goldberg, V.M.; Yoo, J.U.; Johnstone, B. BMP-2 induction and TGF-beta 1 modulation of rat periosteal cell chondrogenesis. J. Cell Biochem. 2001, 81, 284-294. [CrossRef]

99. Oldershaw, A.R.; Baxter, A.M.; Lowe, E.T.; Bates, N.; Grady, L.M.; Soncin, F.; Brison, D.R.; E Hardingham, T.; Kimber, S.J. Directed differentiation of human embryonic stem cells toward chondrocytes. Nat. Biotechnol. 2010, 28, 1187-1194. [CrossRef]

100. Steinert, A.F.; Nöth, U.; Tuan, R.S. Concepts in gene therapy for cartilage repair. Injury 2008, 39, 97-113. [CrossRef]

101. Wang, J.; Caldwell, K.; Lu, Q.; Feng, Y.; Barnthouse, N.; Miller, A. NFAT1 deficiency provokes hypertrophic repair of articular cartilage defects and progression of posttraumatic osteoarthritis. Osteoarthr. Cartil. 2016, 24, S19. [CrossRef]

102. Ko, J.-Y.; Kim, K.-I.; Park, S.; Im, G.-I. In vitro chondrogenesis and in vivo repair of osteochondral defect with human induced pluripotent stem cells. Biomaterials 2014, 35, 3571-3581. [CrossRef] [PubMed]

103. Zhu, Y.; Wu, X.; Liang, Y.; Gu, H.; Song, K.; Zou, X.; Zhou, G. Repair of cartilage defects in osteoarthritis rats with induced pluripotent stem cell derived chondrocytes. BMC Biotechnol. 2016, 16, 1-11. [CrossRef] [PubMed]

104. Li, Y.; Liu, T.; Van Halm-Lutterodt, N.; Chen, J.; Su, Q.; Hai, Y. Reprogramming of blood cells into induced pluripotent stem cells as a new cell source for cartilage repair. Stem Cell Res. Ther. 2016, 7, 1-11. [CrossRef] [PubMed]

105. Rim, Y.A.; Nam, Y.; Park, N.; Jung, H.; Lee, K.; Lee, J.; Ju, J.H. Chondrogenic Differentiation from Induced Pluripotent Stem Cells Using Non-Viral Minicircle Vectors. Cells 2020, 9, 582. [CrossRef] 
106. Koyama, N.; Miura, M.; Nakao, K.; Kondo, E.; Fujii, T.; Taura, D.; Kanamoto, N.; Sone, M.; Yasoda, A.; Arai, H.; et al. Human Induced Pluripotent Stem Cells Differentiated into Chondrogenic LineageViaGeneration of Mesenchymal Progenitor Cells. Stem Cells Dev. 2013, 22, 102-113. [CrossRef]

107. Craft, A.M.; Rockel, J.S.; Nartiss, Y.; A Kandel, R.; A Alman, B.; Keller, G. Generation of articular chondrocytes from human pluripotent stem cells. Nat. Biotechnol. 2015, 33, 638-645. [CrossRef]

108. Lee, J.; Taylor, S.E.B.; Smeriglio, P.; Lai, J.; Maloney, W.J.; Yang, F.; Bhutani, N. Early induction of a prechondrogenic population allows efficient generation of stable chondrocytes from human induced pluripotent stem cells. FASEB J. 2015, 29, 3399-3410. [CrossRef]

109. Boreström, C.; Simonsson, S.; Enochson, L.; Bigdeli, N.; Brantsing, C.; Ellerström, C.; Hyllner, J.; Lindahl, A. Footprint-Free Human Induced Pluripotent Stem Cells From Articular Cartilage With Redifferentiation Capacity: A First Step Toward a Clinical-Grade Cell Source. STEM CELLS Transl. Med. 2014, 3, 433-447. [CrossRef]

110. Yang, S.-L.; Harnish, E.; Leeuw, T.; Dietz, U.; Batchelder, E.; Wright, P.S.; Peppard, J.; August, P.; Volle-Challier, C.; Bono, F.; et al. Compound screening platform using human induced pluripotent stem cells to identify small molecules that promote chondrogenesis. Protein Cell 2012, 3, 934-942. [CrossRef]

111. Saito, T.; Yano, F.; Mori, D.; Kawata, M.; Hoshi, K.; Takato, T.; Masaki, H.; Otsu, M.; Eto, K.; Nakauchi, H.; et al. Hyaline cartilage formation and tumorigenesis of implanted tissues derived from human induced pluripotent stem cells. Biomed. Res. 2015, 36, 179-186. [CrossRef]

112. Yamashita, A.; Morioka, M.; Yahara, Y.; Okada, M.; Kobayashi, T.; Kuriyama, S.; Matsuda, S.; Tsumaki, N. Generation of Scaffoldless Hyaline Cartilaginous Tissue from Human iPSCs. Stem Cell Rep. 2015, 4, 404-418. [CrossRef] [PubMed]

113. Kawata, M.; Mori, D.; Kanke, K.; Hojo, H.; Ohba, S.; Chung, U.-I.; Yano, F.; Masaki, H.; Otsu, M.; Nakauchi, H.; et al. Simple and Robust Differentiation of Human Pluripotent Stem Cells toward Chondrocytes by Two Small-Molecule Compounds. Stem Cell Rep. 2019, 13, 530-544. [CrossRef] [PubMed]

114. Kreuser, U.; Buchert, J.; Haase, A.; Richter, W.; Diederichs, S. Initial WNT/ $\beta$-Catenin Activation Enhanced Mesoderm Commitment, Extracellular Matrix Expression, Cell Aggregation and Cartilage Tissue Yield From Induced Pluripotent Stem Cells. Front. Cell Dev. Biol. 2020, 8, 581331. [CrossRef] [PubMed]

115. Adkar, S.S.; Wu, C.-L.; Willard, V.P.; Dicks, A.; Ettyreddy, A.; Steward, N.; Bhutani, N.; Gersbach, C.A.; Guilak, F. Step-Wise Chondrogenesis of Human Induced Pluripotent Stem Cells and Purification Via a Reporter Allele Generated by CRISPR-Cas9 Genome Editing. Stem Cells 2018, 37, 65-76. [CrossRef] [PubMed]

116. Guzzo, R.M.; Gibson, J.; Xu, R.-H.; Lee, F.Y.; Drissi, H. Efficient differentiation of human iPSC-derived mesenchymal stem cells to chondroprogenitor cells. J. Cell. Biochem. 2012, 114, 480-490. [CrossRef] [PubMed]

117. Nejadnik, H.; Diecke, S.; Lenkov, O.D.; Chapelin, F.; Donig, J.; Tong, X.; Derugin, N.; Chan, R.C.F.; Gaur, A.; Yang, F.; et al Improved Approach for Chondrogenic Differentiation of Human Induced Pluripotent Stem Cells. Stem Cell Rev. Rep. 2015, 11, 242-253. [CrossRef] [PubMed]

118. Diederichs, S.; Gabler, J.; Autenrieth, J.; Kynast, K.L.; Merle, C.; Walles, H.; Utikal, J.; Richter, W. Differential Regulation of SOX9 Protein During Chondrogenesis of Induced Pluripotent Stem Cells Versus Mesenchymal Stromal Cells: A Shortcoming for Cartilage Formation. Stem Cells Dev. 2016, 25, 598-609. [CrossRef]

119. Diederichs, S.; Klampfleuthner, F.A.M.; Moradi, B.; Richter, W. Chondral Differentiation of Induced Pluripotent Stem Cells Without Progression Into the Endochondral Pathway. Front. Cell Dev. Biol. 2019, 7, 270. [CrossRef]

120. Chang, Y.-H.; Wu, K.-C.; Ding, D.-C. Induced Pluripotent Stem Cell-Differentiated Chondrocytes Repair Cartilage Defect in a Rabbit Osteoarthritis Model. Stem Cells Int. 2020, 2020, 1-16. [CrossRef]

121. Aisenbrey, E.A.; Bilousova, G.; Payne, K.; Bryant, S.J. Dynamic mechanical loading and growth factors influence chondrogenesis of induced pluripotent mesenchymal progenitor cells in a cartilage-mimetic hydrogel. Biomater. Sci. 2019, 7, 5388-5403. [CrossRef] [PubMed]

122. Hu, Y.; Chen, L.; Gao, Y.; Cheng, P.; Yang, L.; Wu, C.; Jie, Q. A lithium-containing biomaterial promotes chondrogenic differentiation of induced pluripotent stem cells with reducing hypertrophy. Stem Cell Res. Ther. 2020, 11, 1-13. [CrossRef] [PubMed]

123. Qu, C.; Puttonen, K.; Lindeberg, H.; Ruponen, M.; Hovatta, O.; Koistinaho, J.; Lammi, M. Chondrogenic differentiation of human pluripotent stem cells in chondrocyte co-culture. Int. J. Biochem. Cell Biol. 2013, 45, 1802-1812. [CrossRef] [PubMed]

124. Wei, Y.; Zeng, W.; Wan, R.; Wang, J.; Zhou, Q.; Qiu, S.; Singh, S. Chondrogenic differentiation of induced pluripotent stem cells from osteoarthritic chondrocytes in alginate matrix. Eur. Cells Mater. 2012, 23, 1-12. [CrossRef]

125. Kurosawa, H. Methods for inducing embryoid body formation: In vitro differentiation system of embryonic stem cells. J. Biosci. Bioeng. 2007, 103, 389-398. [CrossRef]

126. Schukur, L.; Zorlutuna, P.; Cha, J.M.; Bae, H.; Khademhosseini, A. Directed Differentiation of Size-Controlled Embryoid Bodies Towards Endothelial and Cardiac Lineages in RGD-Modified Poly(Ethylene Glycol) Hydrogels. Adv. Heal. Mater. 2013, 2, 195-205. [CrossRef]

127. Lee, K.; Kim, C.; Yang, J.Y.; Lee, H.; Ahn, B.; Xu, L.; Kang, J.Y.; Oh, K.W. Gravity-oriented microfluidic device for uniform and massive cell spheroid formation. Biomicrofluidics 2012, 6, 014114-141147. [CrossRef]

128. Dias, A.D.; Unser, A.M.; Xie, Y.; Chrisey, D.B.; Corr, D.T. Generating size-controlled embryoid bodies using laser direct-write. Biofabrication 2014, 6, 025007. [CrossRef] 
129. Sa, S. Round-bottomed Honeycomb Microwells: Embryoid body shape correlates with stem cell fate. J. Dev. Biol. Tissue Eng. 2012, 4, 12-22. [CrossRef]

130. Choi, Y.Y.; Chung, B.G.; Lee, D.H.; Khademhosseini, A.; Kim, J.-H.; Lee, S.-H. Controlled-size embryoid body formation in concave microwell arrays. Biomaterials 2010, 31, 4296-4303. [CrossRef]

131. Hwang, Y.-S.; Chung, B.G.; Ortmann, D.; Hattori, N.; Moeller, H.-C.; Khademhosseini, A. Microwell-mediated control of embryoid body size regulates embryonic stem cell fate via differential expression of WNT5a and WNT11. Proc. Natl. Acad. Sci. USA 2009, 106, 16978-16983. [CrossRef] [PubMed]

132. Cha, J.M.; Bae, H.; Sadr, N.; Manoucheri, S.; Edalat, F.; Kim, K.; Kim, S.B.; Kwon, I.K.; Hwang, Y.-S.; Khademhosseini, A. Embryoid body size-mediated differential endodermal and mesodermal differentiation using polyethylene glycol (PEG) microwell array. Macromol. Res. 2015, 23, 245-255. [CrossRef]

133. Van Winkle, A.P.; Gates, I.; Kallos, M. Mass Transfer Limitations in Embryoid Bodies during Human Embryonic Stem Cell Differentiation. Cells Tissues Organs 2012, 196, 34-47. [CrossRef]

134. Dahlin, R.L.; Ni, M.; Meretoja, V.; Kasper, F.; Mikos, A.G. TGF- $\beta 3$-induced chondrogenesis in co-cultures of chondrocytes and mesenchymal stem cells on biodegradable scaffolds. Biomaterials 2014, 35, 123-132. [CrossRef] [PubMed]

135. Rim, Y.A.; Nam, Y.; Park, N.; Jung, H.; Jang, Y.; Lee, J.; Ju, J.H. Different Chondrogenic Potential among Human Induced Pluripotent Stem Cells from Diverse Origin Primary Cells. Stem Cells Int. 2018, 2018, 9432616. [CrossRef]

136. Nam, Y.; Rim, Y.A.; Jung, S.M.; Ju, J.H. Cord blood cell-derived iPSCs as a new candidate for chondrogenic differentiation and cartilage regeneration. Stem Cell Res. Ther. 2017, 8, 16. [CrossRef] [PubMed]

137. Shen, B.; Wei, A.; Tao, H.; Diwan, A.D.; Ma, D.D. BMP-2 Enhances TGF- $\beta 3-$ Mediated Chondrogenic Differentiation of Human Bone Marrow Multipotent Mesenchymal Stromal Cells in Alginate Bead Culture. Tissue Eng. Part A 2009, 15, 1311-1320. [CrossRef]

138. Lee, H.-H.; Chang, C.-C.; Shieh, M.-J.; Wang, J.-P.; Chen, Y.-T.; Young, T.-H.; Hung, S.-C. Hypoxia Enhances Chondrogenesis and Prevents Terminal Differentiation through PI3K/Akt/FoxO Dependent Anti-Apoptotic Effect. Sci. Rep. 2013, 3, 2683. [CrossRef]

139. Carroll, S.; Buckley, C.; Kelly, D. Cyclic hydrostatic pressure promotes a stable cartilage phenotype and enhances the functional development of cartilaginous grafts engineered using multipotent stromal cells isolated from bone marrow and infrapatellar fat pad. J. Biomech. 2014, 47, 2115-2121. [CrossRef]

140. Allendorph, G.P.; Read, J.D.; Kawakami, Y.; Kelber, J.; Isaacs, M.J.; Choe, S. Designer TGF $\beta$ Superfamily Ligands with Diversified Functionality. PLoS ONE 2011, 6, e26402. [CrossRef]

141. Chen, X.; Yamashita, A.; Morioka, M.; Senba, T.; Kamatani, T.; Watanabe, A.; Kosai, A.; Tsumaki, N. Integration Capacity of Human Induced Pluripotent Stem Cell-Derived Cartilage. Tissue Eng. Part A 2019, 25, 437-445. [CrossRef]

142. Paulsen, D.F.; Langille, R.M.; Dress, V.; Solursh, M. Selective stimulation of in vitro limb-bud chondrogenesis by retinoic acid Differentiation 1988, 39, 123-130. [CrossRef] [PubMed]

143. Diederichs, S.; Tuan, R.S. Functional Comparison of Human-Induced Pluripotent Stem Cell-Derived Mesenchymal Cells and Bone Marrow-Derived Mesenchymal Stromal Cells from the Same Donor. Stem Cells Dev. 2014, 23, 1594-1610. [CrossRef] [PubMed]

144. Narcisi, R.; Arikan, O.H.; Lehmann, J.; Berge, D.T.; van Osch, G.J. Differential Effects of Small Molecule WNT Agonists on the Multilineage Differentiation Capacity of Human Mesenchymal Stem Cells. Tissue Eng. Part A 2016, 22, 1264-1273. [CrossRef]

145. Thompson, C.L.; Wiles, A.; Poole, C.A.; Knight, M.M. Lithium chloride modulates chondrocyte primary cilia and inhibits Hedgehog signaling. FASEB J. 2016, 30, 716-726. [CrossRef] [PubMed]

146. Augustyniak, E.; Trzeciak, T.; Richter, M.; Kaczmarczyk, J.; Suchorska, W. The role of growth factors in stem cell-directed chondrogenesis: A real hope for damaged cartilage regeneration. Int. Orthop. 2015, 39, 995-1003. [CrossRef]

147. Bian, L.; Zhai, D.Y.; Tous, E.; Rai, R.; Mauck, R.; Burdick, J.A. Enhanced MSC chondrogenesis following delivery of TGF- $\beta 3$ from alginate microspheres within hyaluronic acid hydrogels in vitro and in vivo. Biomater. 2011, 32, 6425-6434. [CrossRef]

148. Liu, N.; Lapcevich, R.K.; Underhill, C.B.; Han, Z.; Gao, F.; Swartz, G.; Plum, S.M.; Zhang, L.; Green, S.J. Metastatin: A hyaluronanbinding complex from cartilage that inhibits tumor growth. Cancer Res. 2001, 61, 1022-1028.

149. Hongisto, H.; Ilmarinen, T.; Vattulainen, M.; Mikhailova, A.; Skottman, H. Xeno- and feeder-free differentiation of human pluripotent stem cells to two distinct ocular epithelial cell types using simple modifications of one method. Stem Cell Res. Ther. 2017, 8, 1-15. [CrossRef]

150. Mandai, M.; Watanabe, A.; Kurimoto, Y.; Hirami, Y.; Morinaga, C.; Daimon, T.; Fujihara, M.; Akimaru, H.; Sakai, N.; Shibata, Y.; et al. Autologous Induced Stem-Cell-Derived Retinal Cells for Macular Degeneration. N. Engl. J. Med. 2017, 376, 1038-1046. [CrossRef]

151. Turner, M.; Leslie, S.; Martin, N.; Peschanski, M.; Rao, M.; Taylor, C.J.; Trounson, A.; Turner, D.; Yamanaka, S.; Wilmut, I. Toward the Development of a Global Induced Pluripotent Stem Cell Library. Cell Stem Cell 2013, 13, 382-384. [CrossRef] [PubMed]

152. van der Valk, J.; Mellor, D.; Brands, R.; Fischer, R.; Gruber, F.; Gstraunthaler, G.; Hellebrekers, L.; Hyllner, J.; Jonker, F.; Prieto, P.; et al. The humane collection of fetal bovine serum and possibilities for serum-free cell and tissue culture. Toxicol. Vitr. 2004, 18, 1-12. [CrossRef] [PubMed]

153. Desai, N.; Rambhia, P.; Gishto, A. Human embryonic stem cell cultivation: Historical perspective and evolution of xeno-free culture systems. Reprod. Biol. Endocrinol. 2015, 13, 1-15. [CrossRef] [PubMed]

154. Endo, K.; Fujita, N.; Nakagawa, T.; Nishimura, R. Effect of Fibroblast Growth Factor-2 and Serum on Canine Mesenchymal Stem Cell Chondrogenesis. Tissue Eng. Part A 2019, 25, 901-910. [CrossRef] 
155. Bilgen, B.; Orsini, E.; Aaron, R.K.; Ciombor, D.M. FBS suppresses TGF- $\beta 1$-induced chondrogenesis in synoviocyte pellet cultures while dexamethasone and dynamic stimuli are beneficial. J. Tissue Eng. Regen. Med. 2007, 1, 436-442. [CrossRef]

156. Jing-Li, Z.; Wu, X.-Y.; Tong, J.-B.; Yang, X.-X.; Zhao, J.-L.; Zheng, Q.-F.; Zhao, G.-B.; Ma, Z.-J. Comparative analysis of human mesenchymal stem cells from bone marrow and adipose tissue under xeno-free conditions for cell therapy. Stem Cell Res. Ther. 2015, 6, 1-13. [CrossRef]

157. Cheng, A.; Kapacee, Z.; Peng, J.; Lu, S.; Lucas, R.J.; Hardingham, T.E.; Kimber, S.J. Cartilage Repair Using Human Embryonic Stem Cell-Derived Chondroprogenitors. STEM CELLS Transl. Med. 2014, 3, 1287-1294. [CrossRef]

158. Moskalewski, S.; Hyc, A.; Osiecka-Iwan, A. Immune response by host after allogeneic chondrocyte transplant to the cartilage. Microsc. Res. Tech. 2002, 58, 3-13. [CrossRef]

159. Kimura, T.; Yamashita, A.; Ozono, K.; Tsumaki, N. Limited Immunogenicity of Human Induced Pluripotent Stem Cell-Derived Cartilages. Tissue Eng. Part A 2016, 22, 1367-1375. [CrossRef]

160. Zimmermann, A.; Preynat-Seauve, O.; Tiercy, J.-M.; Krause, K.-H.; Villard, J. Haplotype-Based Banking of Human Pluripotent Stem Cells for Transplantation: Potential and Limitations. Stem Cells Dev. 2012, 21, 2364-2373. [CrossRef]

161. Nakatsuji, N.; Nakajima, F.; Tokunaga, K. HLA-haplotype banking and iPS cells. Nat. Biotechnol. 2008, 26, 739-740. [CrossRef] [PubMed]

162. Yamashita, A.; Liu, S.; Woltjen, K.; Thomas, B.; Meng, G.; Hotta, A.; Takahashi, K.; Ellis, J.; Yamanaka, S.; Rancourt, D.E. Cartilage tissue engineering identifies abnormal human induced pluripotent stem cells. Sci. Rep. 2013, 3, srep01978. [CrossRef] [PubMed]

163. Yamashita, A.; Morioka, M.; Kishi, H.; Kimura, T.; Yahara, Y.; Okada, M.; Fujita, K.; Sawai, H.; Ikegawa, S.; Tsumaki, N. Statin treatment rescues FGFR3 skeletal dysplasia phenotypes. Nature 2014, 513, 507-511. [CrossRef]

164. Goyal, D.; Goyal, A.; Keyhani, S.; Lee, E.H.; Hui, J.H. Evidence-Based Status of Second- and Third-Generation Autologous Chondrocyte Implantation Over First Generation: A Systematic Review of Level I and II Studies. Arthrosc. J. Arthrosc. Relat. Surg. 2013, 29, 1872-1878. [CrossRef] [PubMed]

165. Huang, C.-Y.; Liu, C.-L.; Ting, C.-Y.; Chiu, Y.-T.; Cheng, Y.-C.; Nicholson, M.W.; Hsieh, P.C.H. Human iPSC banking: Barriers and opportunities. J. Biomed. Sci. 2019, 26, 1-14. [CrossRef] [PubMed]

166. Chamberlain, S.J. Disease modelling using human iPSCs. Hum. Mol. Genet. 2016, 25, R173-R181. [CrossRef] [PubMed]

167. Liu, H.; Yang, L.; Yu, F.; Wang, S.; Wu, C.; Qu, C.; Lammi, M.; Guo, X. The potential of induced pluripotent stem cells as a tool to study skeletal dysplasias and cartilage-related pathologic conditions. Osteoarthr. Cartil. 2017, 25, 616-624. [CrossRef]

168. Kim, T.-W.; Che, J.-H.; Yun, J.-W. Use of stem cells as alternative methods to animal experimentation in predictive toxicology. Regul. Toxicol. Pharmacol. 2019, 105, 15-29. [CrossRef]

169. Kimura, T.; Ozaki, T.; Fujita, K.; Yamashita, A.; Morioka, M.; Ozono, K.; Tsumaki, N. Proposal of patient-specific growth plate cartilage xenograft model for FGFR3 chondrodysplasia. Osteoarthr. Cartil. 2018, 26, 1551-1561. [CrossRef]

170. Horie, N.; Hikita, A.; Nishizawa, S.; Uto, S.; Takato, T.; Hoshi, K. Impairment of the transition from proliferative stage to prehypertrophic stage in chondrogenic differentiation of human induced pluripotent stem cells harboring the causative mutation of achondroplasia in fibroblast growth factor receptor 3. Regen. Ther. 2017, 6, 15-20. [CrossRef]

171. Pretemer, Y.; Kawai, S.; Nagata, S.; Nishio, M.; Watanabe, M.; Tamaki, S.; Alev, C.; Yamanaka, Y.; Xue, J.-Y.; Wang, Z.; et al Differentiation of Hypertrophic Chondrocytes from Human iPSCs for the In Vitro Modeling of Chondrodysplasias. Stem Cell Rep. 2021, 16, 610-625. [CrossRef]

172. Okada, M.; Ikegawa, S.; Morioka, M.; Yamashita, A.; Saito, A.; Sawai, H.; Murotsuki, J.; Ohashi, H.; Okamoto, T.; Nishimura, G.; et al. Modeling type II collagenopathy skeletal dysplasia by directed conversion and induced pluripotent stem cells. Hum. Mol. Genet. 2015, 24, 299-313. [CrossRef] [PubMed]

173. Xu, M.; Stattin, E.-L.; Shaw, G.; Heinegård, D.; Sullivan, G.; Wilmut, I.; Colman, A.; Önnerfjord, P.; Khabut, A.; Aspberg, A.; et al. Chondrocytes Derived From Mesenchymal Stromal Cells and Induced Pluripotent Cells of Patients With Familial Osteochondritis Dissecans Exhibit an Endoplasmic Reticulum Stress Response and Defective Matrix Assembly. STEM CELLS Transl. Med. 2016, 5, 1171-1181. [CrossRef] [PubMed]

174. Yokoyama, K.; Ikeya, M.; Umeda, K.; Oda, H.; Nodomi, S.; Nasu, A.; Matsumoto, Y.; Izawa, K.; Horigome, K.; Kusaka, T.; et al. Enhanced Chondrogenesis of Induced Pluripotent Stem Cells From Patients With Neonatal-Onset Multisystem Inflammatory Disease Occurs via the Caspase 1-Independent cAMP/Protein Kinase A/CREB Pathway. Arthritis Rheumatol. 2014, 67, 302-314. [CrossRef] [PubMed]

175. Saitta, B.; Passarini, J.; Sareen, D.; Ornelas, L.; Sahabian, A.; Argade, S.; Krakow, D.; Cohn, D.H.; Svendsen, C.N.; Rimoin, D.L. Patient-Derived Skeletal Dysplasia Induced Pluripotent Stem Cells Display Abnormal Chondrogenic Marker Expression and Regulation by BMP2 and TGF $\beta 1$. Stem Cells Dev. 2014, 23, 1464-1478. [CrossRef]

176. Matsumoto, Y.; Ikeya, M.; Hino, K.; Horigome, K.; Fukuta, M.; Watanabe, M.; Nagata, S.; Yamamoto, T.; Otsuka, T.; Toguchida, J New Protocol to Optimize iPS Cells for Genome Analysis of Fibrodysplasia Ossificans Progressiva. Stem Cells 2015, 33, 1730-1742. [CrossRef] [PubMed]

177. Castro-Viñuelas, R.; Sanjurjo-Rodríguez, C.; Piñeiro-Ramil, M.; Hermida-Gómez, T.; Rodríguez-Fernández, S.; Oreiro, N.; De Toro, J.; Fuentes, I.; Blanco, F.J.; Díaz-Prado, S. Generation and characterization of human induced pluripotent stem cells (iPSCs) from hand osteoarthritis patient-derived fibroblasts. Sci. Rep. 2020, 10, 4272. [CrossRef]

178. Rim, Y.; Nam, Y.; Park, N.; Lee, K.; Jung, H.; Jung, S.; Lee, J.; Ju, J. Characterization of Early-Onset Finger Osteoarthritis-Like Condition Using Patient-Derived Induced Pluripotent Stem Cells. Cells 2021, 10, 317. [CrossRef] 
179. Lin, Z.; Li, Z.; Li, E.N.; Li, X.; Del Duke, C.J.; Shen, H.; Hao, T.; O’Donnell, B.; Bunnell, B.; Goodman, S.B.; et al. Osteochondral Tissue Chip Derived From iPSCs: Modeling OA Pathologies and Testing Drugs. Front. Bioeng. Biotechnol. 2019, 7, 411. [CrossRef]

180. Zhou, Z.-Q.; Ota, S.; Deng, C.; Akiyama, H.; Hurlin, P.J. Mutant activated FGFR3 impairs endochondral bone growth by preventing SOX9 downregulation in differentiating chondrocytes. Hum. Mol. Genet. 2014, 24, 1764-1773. [CrossRef]

181. Zhou, S.; Xie, Y.; Li, W.; Huang, J.; Wang, Z.; Tang, J.; Xu, W.; Sun, X.; Tan, Q.; Huang, S.; et al. Conditional Deletion of Fgfr3 in Chondrocytes leads to Osteoarthritis-like Defects in Temporomandibular Joint of Adult Mice. Sci. Rep. 2016, 6, 24039. [CrossRef] [PubMed]

182. Briggs, M.D.; Dennis, E.; Dietmar, H.F.; Pirog, K.A. New developments in chondrocyte ER-stress and related diseases F1000Research 2020, 9, 290. [CrossRef] [PubMed]

183. Mäkitie, O.; Susic, M.; Ward, L.; Barclay, C.; Glorieux, F.H.; Cole, W.G. Schmid type of metaphyseal chondrodysplasia andCOL10A1mutations-findings in 10 patients. Am. J. Med Genet. Part A 2005, 137A, 241-248. [CrossRef] [PubMed]

184. Mäkitie, O.; Mortier, G.; Czarny-Ratajczak, M.; Wright, M.J.; Suri, M.; Rogala, P.; Freund, M.; Jackson, G.C.; Jakkula, E.; Ala-Kokko, L.; et al. Clinical and radiographic findings in multiple epiphyseal dysplasia caused by MATN3 mutations: Description of 12 patients. Am. J. Med Genet. Part A 2004, 125A, 278-284. [CrossRef] [PubMed]

185. Muttigi, M.S.; Han, I.; Park, H.-K.; Park, H.; Lee, S.-H. Matrilin-3 Role in Cartilage Development and Osteoarthritis. Int. J. Mol. Sci. 2016, 17, 590. [CrossRef] [PubMed]

186. Xu, J.; Wang, W.; Ludeman, M.; Cheng, K.; Hayami, T.; Lotz, J.C.; Kapila, S. Chondrogenic Differentiation of Human Mesenchymal Stem Cells in Three-Dimensional Alginate Gels. Tissue Eng. Part A 2008, 14, 667-680. [CrossRef]

187. Nenna, R.; Turchetti, A.; Mastrogiorgio, G.; Midulla, F. COL2A1 Gene Mutations: Mechanisms of Spondyloepiphyseal Dysplasia Congenita. Appl. Clin. Genet. 2019, ume 12, 235-238. [CrossRef]

188. Nishimura, G.; Haga, N.; Kitoh, H.; Tanaka, Y.; Sonoda, T.; Kitamura, M.; Shirahama, S.; Itoh, T.; Nakashima, E.; Ohashi, H.; et al. The phenotypic spectrum ofCOL2A1mutations. Hum. Mutat. 2005, 26, 36-43. [CrossRef]

189. Fosang, A.J.; Beier, F. Emerging Frontiers in cartilage and chondrocyte biology. Best Pr. Res. Clin. Rheumatol. 2011, 25, 751-766. [CrossRef]

190. Nikitovic, D.; Aggelidakis, J.; Young, M.F.; Iozzo, R.; Karamanos, N.; Tzanakakis, G. The Biology of Small Leucine-rich Proteoglycans in Bone Pathophysiology. J. Biol. Chem. 2012, 287, 33926-33933. [CrossRef]

191. Jenei-Lanzl, Z.; Meurer, A.; Zaucke, F. Interleukin-1 $\beta$ signaling in osteoarthritis-chondrocytes in focus. Cell. Signal. 2019, 53, 212-223. [CrossRef] [PubMed]

192. Kelley, N.; Jeltema, D.; Duan, Y.; He, Y. The NLRP3 Inflammasome: An Overview of Mechanisms of Activation and Regulation. Int. J. Mol. Sci. 2019, 20, 3328. [CrossRef] [PubMed]

193. Bonar, S.L.; Brydges, S.D.; Mueller, J.L.; McGeough, M.D.; Pena, C.; Chen, D.; Grimston, S.K.; Hickman-Brecks, C.L.; Ravindran, S.; McAlinden, A.; et al. Constitutively Activated NLRP3 Inflammasome Causes Inflammation and Abnormal Skeletal Development in Mice. PLoS ONE 2012, 7, e35979. [CrossRef] [PubMed]

194. Everaerts, W.; Nilius, B.; Owsianik, G. The vanilloid transient receptor potential channel TRPV4: From structure to disease. Prog. Biophys. Mol. Biol. 2010, 103, 2-17. [CrossRef] [PubMed]

195. Geneviève, D.; Le Merrer, M.; Feingold, J.; Munnich, A.; Maroteaux, P.; Cormier-Daire, V. Revisiting metatropic dysplasia: Presentation of a series of 19 novel patients and review of the literature. Am. J. Med Genet. Part A 2008, 146A, 992-996. [CrossRef]

196. Graversen, L.; Haagerup, A.; Andersen, B.N.; Petersen, K.K.; Gjørup, V.; Gudmundsdottir, G.; Vogel, I.; Gregersen, P.A. Novel TRPV4 variant causes a severe form of metatropic dysplasia. Clin. Case Rep. 2018, 6, 1774-1778. [CrossRef] [PubMed]

197. Matsumoto, Y.; Hayashi, Y.; Schlieve, C.R.; Ikeya, M.; Kim, H.; Nguyen, T.D.; Sami, S.; Baba, S.; Barruet, E.; Nasu, A.; et al Induced pluripotent stem cells from patients with human fibrodysplasia ossificans progressiva show increased mineralization and cartilage formation. Orphanet J. Rare Dis. 2013, 8, 190. [CrossRef]

198. Petrie, K.A.; Lee, W.H.; Bullock, A.N.; Pointon, J.J.; Smith, R.; Russell, R.G.G.; Brown, M.A.; Wordsworth, B.P.; Triffitt, J.T. Novel Mutations in ACVR1 Result in Atypical Features in Two Fibrodysplasia Ossificans Progressiva Patients. PLoS ONE 2009, 4, e5005. [CrossRef]

199. Hino, K.; Ikeya, M.; Horigome, K.; Matsumoto, Y.; Ebise, H.; Nishio, M.; Sekiguchi, K.; Shibata, M.; Nagata, S.; Matsuda, S.; et al. Neofunction of ACVR1 in fibrodysplasia ossificans progressiva. Proc. Natl. Acad. Sci. USA 2015, 112, 15438-15443. [CrossRef]

200. Kumar, M.; Wadhwa, S.; Tyagi, N.; Ahmad, I.; Kumar, S.; Sagar, S.; Zahra, S.; Kamai, A.; Shamim, U.; Kapoor, S.; et al. Generation of induced pluripotent stem cell line (IGIBi007-A) from a patient with a novel acromesomelic dysplasia, PRKG2 type (AMDP). Stem Cell Res. 2021, 53, 102340. [CrossRef]

201. Chen, M.; Lin, S.M.; Li, N.; Li, Y.; Li, Y.; Zhang, L. An induced pluripotent stem cell line (GZHMCi003-A) derived from a fetus with exon 3 heterozygous deletion in RUNX2 gene causing cleidocranial dysplasia. Stem Cell Res. 2021, 51, 102166. [CrossRef] [PubMed] 